UNITED STATES DEPARTMENT OF THE INTERIOR

Harold L. Ickes, Secretary

GEOLOGICAL SURVEY

W. C. Mendenhall, Director

Bulletin 917-C

\title{
PAST LODE-GOLD PRODUCTION FROM ALASKA
}

BY

\author{
PHILIP S. SMITH
}

Mineral resources of Alaska, 1938

(Pages 159-212)

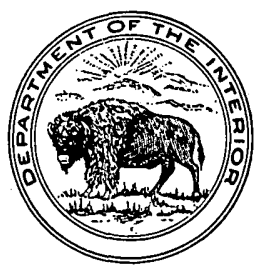

UNITED STATES

GOVERNMENT PRINTING OFFICE

WASHINGTON : 1941

For sale by the Superintendent of Documents, Washington, D. C. . - . - - Price 10 cents 



\section{CONTENTS}

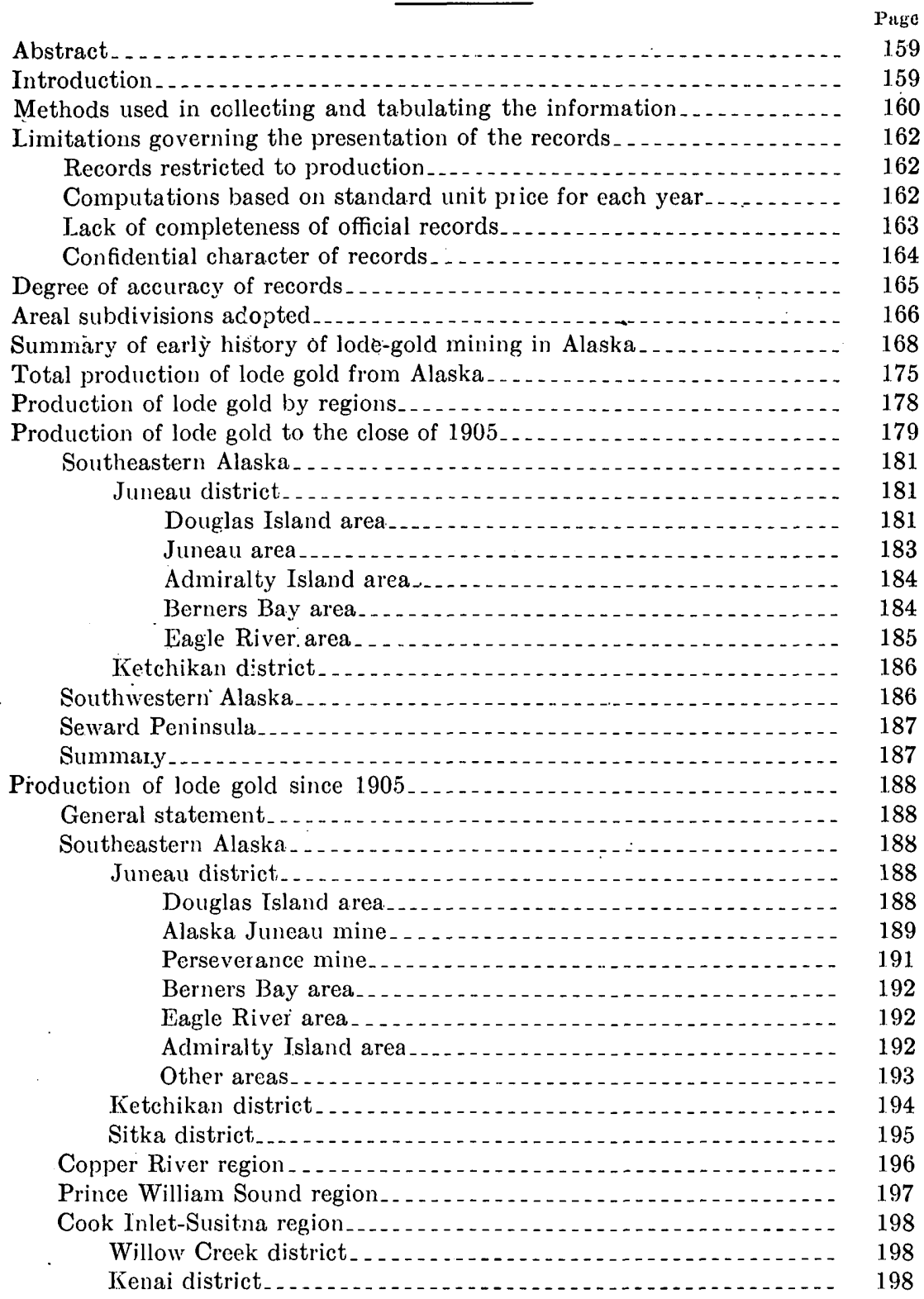


Production of lode gold since 1905-Continued.

Southwestern Alaska..................................... 200

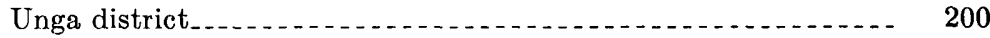

Other districts . . . . . . . . 200

Yukon region $\ldots \ldots 1$

Fairbanks district. $\ldots \ldots \ldots$

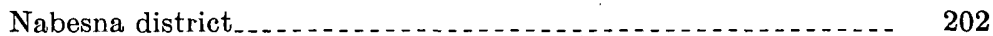

Other districts

Kuskokwim region

McKinley district.

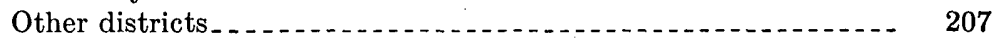

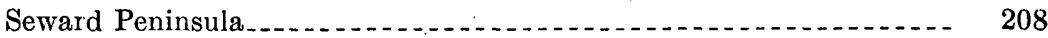

Unidentified regions...... 209

Index $\ldots \ldots \ldots \ldots$

\section{ILLUSTRATION}

Fig URE 6. Lode-gold production from Alaska mines, 1882-1937

\section{TABLES}

TA BLE 1. Lode-gold production of Alaska by regions, for period 1882-1937_ 178

2. Lode-gold production from Alaska by areas, 1882-1905 ....... 180

3. Lode-gold production from mines on Douglas Island, 1882-1905_ 182

4. Lode-gold production of Alaska Juneau mine, 1901-5 _ . . . . . 183

5. Total lode-gold production from Alaska by areas, 1882-1937_. 187 


\title{
PAST LODE-GOLD PRODUCTION FROM ALASKA
}

\author{
By Philip S. Smith
}

\begin{abstract}
This report presents an analysis of the statistical records of the Geological Survey regarding the production of lode gold from the Territory of Alaska for the period 1882 to 1937 , inclusive. During that time lode gold to the value of $\$ 172,368,000$ had been mined. The history of the discovery of lode gold and the early developments in lode-gold mining in each of the various districts is outlined briefly, and the production of lode gold in each of the geographic subdivisions is tabulated fully for each year, as far as the records and the practices of the Geological Survey permit. The records for the larger geographic subdivisions show that lode gold to the value of $\$ 150,775,000$, or 87.5 percent of the total production of the Territory, came from mines in soutbeastern Alaska. The Cook Inlet-Susitna region stands second, with a production for the period of nearly $\$ 9,774,000$, or about 5.7 percent. The remainder, approximately $\$ 12,820,000$, equal to 6.8 percent of the total, came from mines in the following regions, named in the order of their standing as producers of lode gold: Yukon, Prince William Sound, southwestern Alaska, Kuskokwim, Seward Peninsula, and Copper River.
\end{abstract}

\section{INTRODUCTION}

Mines in Alaska had produced, up to the close of 1937, lode gold to the value of more than $\$ 172,000,000$, or more than one-third of all the gold that had been recovered by any type of mining in the 'Territory. Although the greater part of the lode-gold production came from a few large mines, the yield from many small properties widely scattered throughout Alaska was responsible for contributing in the aggregate gold worth many tens of millions of dollars. The lodegold mining industry has, therefore, played an important role in the stages of economic development that Alaska has passed through. Large as has been the production of lode gold from the Territory in the past it is believed to be only a small part of that which ultimately will be afforded by the lode-gold deposits that are already known or that await discovery and development. It seems evident, if this belief is well founded, that lode-gold mining will play an even more important part in the future development of the Territory, so that its growth should be carefully fostered if the best interests of the country are to be served. 
Statistics of the past mineral production are of interest as records of performance, but they are of special significance in pointing out those areas whose histories encourage expectation of future productive developments. The value of such records for this double purpose has long been recognized by the Geological Survey, and to meet the call for that service it has issued annually for more than 35 years a volume on the mineral industry of Alaska, including information on lode-gold mining for the preceding year. Though fulfilling the main purpose for which they were designed, giving current information on minerals, these volumes cannot, without devoting undue space, give much attention to the longer-range aspects of any of the mining industries. Certain restrictions, which do not obtain for older records, are also imposed on the publication of current statistics. Some of these restrictions will be referred to in more detail on pages $162-165$.

It is therefore evident that at infrequent intervals it is desirable to supplement the annual statements by assembling in one place the widely scattered records for a specific mining industry covering a considerable number of years. This, then, is the main object of the following report. Primarily, the statistics given have been computed from the records of the annual canvasses made by the Geological Survey and in general have followed the same principles that were adopted in the original tabulation of those records. Inasmuch, however, as some liberty has been taken in the application of those principles in this report, it seems desirable before discussing the statistics themselves to explain rather fully just what the Geological Survey statistics cover, how the basal facts for their preparation are obtained, and the limitations that restrict full use of the data thus gathered.

\section{METHODS USED IN COLLECTING AND TABULATING THE INFORMATION}

In order that the reader may be informed of the general practice that the Geological Survey follows in collecting information such as that from which the following tabulations are made, it seems desirable to quote certain significant parts of a recent statement bearing on the matter: ${ }^{1}$

To obtain the information recorded in these reports the Geological Survey, in addition to its other investigations of mineral resources, conducts an annual canvass of the entire mineral industry of Alaska. The collection of the facts

\footnotetext{
${ }^{1}$ Smith, P. S., The mineral industry of Alaska in $1936:$ U. S. Geol. Survey Bull. $897-A$, pp. 1-3, 1938 .
} 
requisite for the preparation of these annual statements involves difficulties, because the great size of the Territory, the diversity of its mineral products, and the large number but small size of many of the enterprises make it impracticable without undue delay and expense to gather all the desired information at first hand. The information used is therefore derived from many sources, which necessarily vary in reliability and completeness. Efforts are made, however, to reduce all the statements to a comparable basis and to give only those that appear to be well substantiated. Among the inost reliable sources of information are the geologists and engineers who are sent out each year by the Geological Survey to conduct surveys in different parts of Alaska and who acquire not only much accurate information regarding the mineral production of the regions in which they work but also general information by contact with miners and operators in the course of their travels to and from the field. Members of other Government organizations-for instance, the Bureau of Mines, the Bureau of the Mint, The Alaska Railroad, the Bureau of Foreign and Domestic Commerce, and the Customs Service-in the course of their regular duties collect many data which are extremely valuable in these studies and the use of which avoids unnecessary duplication in collecting records. Most of the banks, express companies, and other business organizations in Alaska collect for their own use data regarding mineral commodities of their particular districts. Some of these data are extremely pertinent to the general inquiry conducted by the Geological Survey, and through the cordial cooperation of many of these companies important facts have been made available to the Survey, though some of this information is confidential and is not released for publication. Most of the larger Alaska newspapers and certain papers published in the States that feature Alaska matters are courteously sent by their publishers to the Geological Survey, and from these and the technical and scientific periodicals are gleaned many items regarding new developments.

In addition to all these general sources the Geological Survey each year sends out hundreds of schedules-one to every person or company known to be engaged in mining in Alaska-on which are questions regarding the mining developments and production of each individual property during the year. These schedules when filled out by the operators of course constitute a most authoritative record. Unfortunately, however, not all of them are returned by the operators, and even some of the operators who return them have not all the specific data desired, misunderstand the inquiries, or reply in such a manner that the answers may not be correctly interpreted when the schedules are edited. It is gratifying evidence of the general appreciation of these annual summaries, that so many of the operators cooperate fully and cordially with the Geological Survey by furnishing the information called for on the schedules as well as volunteering much other pertinent information.

It is apparent, however, that facts collected from one source, although of themselves strictly accurate, are likely to be computed or stated on a different basis from equally reliable reports received from another source, so that considerable editing and revision must be done to bring all to one standard. It is not possible to know exactly all the corrections that should be applied in order to reduce the reports of production to a strictly uniform standard. However, though some uncertainties necessarily remain, it is believed that they do not have significant effect on the results expressed and that the report is consistent within itself and with the other reports of this series which record the statistics of mineral production. 


\section{LIMITATIONS GOVERNING THE PRESENTATION OF THE RECORDS}

It is of prime importance that the reader keep constantly in mind that the statistics and statements given in this report relate exclusively to the period ending December 1937, unless some other period is specifically indicated. He should also understand that the basic facts on which the statistics in this volume, as well as in the annual reports on the mineral industry of Alaska, have been computed relate to mine production during a single calendar year, computed at a standard price for the commodity.

\section{RECORDS RESTRICTED TO PRODUCTION}

Because of the restriction that the statistics relate to production it necessarily follows that the amounts stated in this report may differ greatly from other equally reliable statistics, which are designed to record sales, shipments, reserves, receipts at mints or assay offices, or some other worth-while incident in the long chain of events between discovery of the ore and the final disposal of its products. Thus it is readily evident that ore mined during one calendar year may not be shipped, or received by smelters or mints, or reach its final destination until an entirely different calendar year. Necessarily, if mining is continuing at an even rate this lag is compensated by the fact that the ore mined late in one calendar year but not shipped or finally disposed of until the next calendar year is about offset by that mined or disposed of during the similar period in the preceding or succeeding year. But at best reports computed on any of these other bases will not exactly correspond with these reports on production. Some company records kept for the fiscal year rather than the calendar year therefore do not coincide exactly with the amounts tabulated by the Geological Survey for a specified calendar year, though in the long run the two records essentially balance.

\section{COIIPUTATIONS BASED ON STANDARD UNIT PRICE FOR EACH YEAR}

All the computations that the Geological Survey makes to determine the value of the mineral output are based on a uniform unit price of the commodity for the year specified. The adoption of a standard unit price for the commodity aims at removing the inequalities that would result if the variable price paid to different producers had been used. Obviously, the price paid by a merchant or bank for gold or any other commodity is determined by deducting'various charges for handling, treatment, transportation, and insurance from the theoretical value of the material purchased. No 
such charges or operating expenses should be included in the estimates of the value of an individual's gold production if individual differences are to be disregarded and all reports reduced to a uniform standard. The standard price paid for gold by the Goverment mińts and assay offices was officially fixed at $\$ 20.67+$ an ounce during the entire period prior to 1933 . During 1933 the official price fluctuated widely but by the end of that year had been set by the Government at $\$ 35$ an ounce and has remained fixed at that figure to date. In order to avoid the confusion and uncertainty that would occur in trying to ascertain the actual price paid at the time of sale for each lot of gold produced from Alaskan mines in 1933 it has been assumed in the following computation that the old price of $\$ 20.67+$ an ounce prevailed unchanged throughout the year and that during 1934 and later years the standard price was $\$ 35$ an ounce. The adoption for this report of the old price of gold as standard for 1933 undoubtedly has resulted in an understatement of the amount actually received by Alaska gold miners for their production that year, because on a strict mathematical analysis of the fluctuations that took place the average price of gold for that year was probably between $\$ 5$ and $\$ 6$ higher. Had this higher average price been used in the Survey's computations, the total value of the Alaska lode-gold production for 1933 would have been more than $\$ 1,000,000$ greater than that stated. In fact, for one of the largest gold mines the value of its output for that year as reported by the company in its published annual report, based on its actual receipts, was more than $\$ 700,000$ larger than the figures for that company used in the tabulations recorded by the Geological Survey.

\section{LACK OF COMPLETENESS OF OFFICIAL RECORDS}

In spite of the intention that the following statements should be based primarily on the records obtained by the Geological Survey in the course of its annual canvasses, it has not proved practicable to adhere rigidly to this plan. The most effective bar to carrying out this plan is the fact that prior to 1905 the Geological Survey had not systematized the collection of data on the mineral industry and therefore does not have specific information regarding the individual producers. Many partial records had been collected by the Geological Survey during this early period in the course of its investigation of individual areas or subjects, and these have been utilized fully in the following report. Owing to the differences in the completeness of the basic data for the period before 1906, as contrasted with that for the period from 1906 to 1937, inclusive, it has been found desirable to discuss the records for these two periods separately. 
Even in the period subsequent to 1905 , for which fairly complete Geological Survey records are available, there are necessarily many reasons why a complete break-down of the statistics cannot now be made. In the first place, some of the original records have been lost, so that the specific data they contained cannot be reviewed. Then, too, the records of some of the individual properties had been grouped with others, so that at this late date it is no longer practicable to discover the proper amounts that should be credited to each. Even at best, some of the properties do not furnish the specific records of their year's work, and estimates must be made of their output, based on less specific information, which is not only subject to less accuracy but is less detailed.

\section{CONFIDENTIAL CHARACTER OF RECORDS}

Another effective bar, however, to a complete break-down of the Survey's records of mineral production arises from the necessity of adhering to its promise that the confidential character of all individual operations reported to it shall be scrupulously observed. As a result of this promise the Geological Survey in its annual volumes does not disclose its records of the output of individuals or companies but groups several operations, so that the records of not less than three mines will be tabulated together. The reason for the strict observance of the confidential character of these individual reports is patent. As the reports furnished the Geological Survey are obtained entirely through the voluntary cooperation of the miners, it is evident that only by the most faithful adherence to its obligation to utilize these records only in the way promised has the cordial relationship between the miners of the Territory and the Geological Survey been established and built up.

With the passage of time many of the reasons for not disclosing an individual's operations become less cogent and finally entirely disappear. It therefore seems permissible for the Geological Survey to utilize separately some of the records that heretofore had been consolidated. However, in order that the slight relaxation of the Survey's general policy in handling confidential material, which has been permitted in this report, may be clearly understood the following limitations should be noted:

1. The relaxation of strict adherence to the confidential character of individual reports in this volume does not in any way change the Survey's usual practice in its current mineral-industry volumes. 
2. The records of individual operators are not disclosed in this report unless

(a) Essentially similar records have been published in regular public reports, such, for instance, as those published by the Alaski Juneau Gold Mining Co. and the Nabesna Mining Corporation.

(b) Essentially similar records are publicly published in generally accessible form, such as mining and technical magazines and Geological Survey reports, and reference is given to the specific publication in which such reports appear.

(c) Specific permission has been obtained from the responsible officials for release of their company's reports, as, for example, the records of the Chichagoff mine.

(d) The individual company to which the statistics relate has long discontinued active mining operations in Alaska, as, for example, the Apollo Consolidated Mines on Unga Island and the records of the old Perseverance mine near Juneau before the mine became part of the Alaska Juneau Co. property.

(e) The statistics relate to a period at least 5 years prior to the date of preparation of this report.

Only subdivisions $(d)$ and $(e)$ of the foregoing list of exceptions mark any significant change in the Survey's treatment of individual records, and it is believed that these exceptions will in no way adversely affect the company or individual to whom the statistics relate. In fact it is not intended to utilize extensively either of the relaxations that these two exceptions would permit, for to attempt to break down the production from the districts and areas into individual mines would go far beyond the scope that is possible or worth while in a report of this sort.

\section{DEGREE OF ACCURACY OF RECORDS}

Owing to the methods used in collecting the fundamental data it is readily apparent that the totals for the Territory as a whole and for its larger subdivisions are more accurate than for some of the smaller parts, though the degree of accuracy is such that even for the larger parts it has lately not seemed expedient to state values closer than to the nearest thousand dollars. This has been the practice since 1926 in reporting the total production of the Territory and that of its larger subdivisions. However, the necessities imposed by the strict application of mathematical processes in tabulating together specific reports and estimates have given the figures carried for many of the smaller subdivisions an appearance of far greater accuracy than is entirely justified. For instance, the total lode-gold production of southeastern Alaska in 1930, as determined by individual reports and estimates, was computed to have been $\$ 3,639,000$ - correct to the near- 
est thousand dollars. If this is broken down into various specified districts and further subdivided by smaller areas and mines, it leaves a mathematical remainder of $\$ 2,141$ for other mines in the Juneau district and \$2,000 for mines in the Ketchikan-Hyder district. Although these sums were in part derived from specific reports and in part from estimates, they give every appearance of greater exactness than can be claimed for them, but perforce must be used or the total for the year does not balance. Equal difficulty would have had to be faced if only rounded numbers for each of the subdivisions had been used, because the yearly totals were derived through use of specific reports combined with equally specific estimated amounts. In choosing between disregarding all the hitherto published figures by arbitrarily rounding off individual records or adhering to a strict mathematical procedure, which gives results that appear excessively exact, the writer has adopted the last-named alternative as the least objectionable. This course has been adopted in spite of full awareness that the summation of the available records for a single district for the 56 years covered by the table may introduce errors amounting to several thousand dollars, so that the expression of the total lodegold output of a district down to a single dollar is especially absurd.

\section{AREAL SUBDIVISIONS ADOPTED}

In presenting the accompanying data it has been desirable to make certain rather arbitrary subdivisions of the Territory, which, according to current Survey practice, are called regions and conform more or less closely with the major geographic subdivisions of the country. There are eight such regions in which some productive lode mining has been done. Named in general geographic order from south to north and from east to west, they are as follows: Southeastern Alaska, Copper River, Prince William Sound, Cook Inlet-Susitna, southwestern Alaska, Yukon, Kuskokwim, and Seward Peninsula. Many of these regions have been further subdivided into smaller tracts. The largest of these are called districts, the parts of a district are called areas or camps, and the smallest of all are the individual mining properties. The boundaries of the districts or areas are more or less artificial and do not relate to any specific tract marked on the ground or defined by law. 'They do, however, serve the useful purpose of bringing together parts of the country where more or less similar conditions prevail and separate them from more remote parts or those in which the conditions are different.

In the selection of the subdivisions to be shown in the following tables, the writer has been guided in large part by the character of the information at his disposal. Thus for southeastern Alaska, for 
which there are especially full records that are not of a confidential character, it has been practicable to break them down not only by districts and smaller areas but in some cases even into those of individual mines. It has not been practicable to subdivide the Prince William Sound region at all, even though it embraces almost as large an area as southeastern Alaska. In other words, in the tabulations given the writer has striven to present the available data as fully as appeared useful and practicable, though not with equal minuteness, for the different Alaska regions or camps.

It will be noted that for several of the districts for which some subdivision has been practicable there have been included columns headed "Other areas." For instance, a column of this sort is included in the subdivision of the Juneau district of southeastern Alaska. In general it is intended that the figures shown in this column should relate solely to areas other than those for which columns have been provided. Unfortunately, however, it has not always been possible to determine the precise source of the gold tabulated in the "Other areas" columns. It is not at all unlikely, therefore, that some gold thus included should have been allocated to some of the specified areas. Inasmuch as the total gold carried in the "Other areas" columns for all of the regions of the Territory is only a little more than $\$ 1,000,000$, the largest amounts that may be involved are very small and for all practical purposes are believed to be so trivial that they may be disregarded. For instance, all of the item' of $\$ 600,000$ attributed to "Other areas" in the Juneau district prior to 1906 is correctly allocated as not having come from any of the areas specifically tabulated in the other columns for the district. So, too, the total of $\$ 269,118$, attributed to "Other areas" in the Sitka district, did not come from either of the two main areas in the district whose production is specifically set down in the appropriate columns.

Changes in the ownership of certain properties make it difficult to combine or differentiate correctly some of the records. For instance, in the area immediately east of Juneau much of the gold that was recovered in the early days came from claims that subsequently passed into the ownership of the Alaska Juneau Gold Mining Co., or of the Perseverance mine. In fact, now the Perseverance property itself has been acquired by the Alaska Juneau, so that such ore as now comes from it is credited solely to the present owners. On the whole, however, the writer has made no attempt to trace closely property ownership, except as reported by the company operating at the time the original reports were filed. 


\section{SUMMARY OF EARLY HISTORY OF LODE-GOLD MINING IN ALASKA}

Before discussing in detail the records of lode production from the various Alaska camps, it is desirable to note briefly in chronological order the dates on which lode gold was discovered in some of the more important areas, as well as to give references to the available reports in which the history and early development of the different areas are described. Such a summary necessarily aims at presenting only the more noteworthy events in the early history of each area and by no means is a substitute for the more adequate reports that have been published for all of the more productive areas.

The earliest recorded development of lode-gold deposits in Alaska appears to have been that which took place in the immediate vicinity of Sitka in 1871. These discoveries were made in the valley of Indian Creek, only a mile or so from Sitka, which was then the capital. They do not seem to have resulted in any significant production, and though a 10-stamp mill was built at one of the properties in $1879^{2}$ it had practically ceased operations by 1880, according to Petrof. ${ }^{3}$ By 1881 most of the prospectors had abandoned their search near Sitka and joined in the rush that was in progress to the more promising finds that had been made in the vicinity of Juneau.

Early in 1880 quartz veins were discovered at Windham Bay, some 60 miles southeast of Juneau, but little productive development was undertaken at that time, as the prospectors soon joined in the stampede to the later discoveries near Juneau. It was 1900 before productive lode mines were developed in the Windham Bay area.

Late in 1880 the gold placers and quartz veins were discovered in the Silver Bow Basin, east of the present city of Juneau, and in the vicinity of Douglas, west of Juneau. Some of the interesting early history of the developments at these places has been sketched by Spencer. ${ }^{4}$ The lode properties near Douglas began to yield small amounts of gold by 1882 and large amounts by 1885 , but those in the Silver Bow Basin did not begin production until 1885 and did not become significant producers until several years later.

With the influx of gold seekers to the Juneau area, search for lodes was gradually expanded to some of the more remote parts of the district. As a result, gold-bearing quartz veins were found on Admiralty Island in 1885, and prospecting began there, though without yielding any considerable amount of gold until much later. So too,

\footnotetext{
${ }^{2}$ Knopf, Adolph, The Sitka mining district, Alaska : U. S. Geol. Survey Bull. 504, p. 8, 1912.

3 Petrof, Ivan, Report on the population, industries, and resources of Alaska: 10th Census, 1880 , vol. 8 , p. 30.

- Spencer, A. C., The Juneau gold belt, Alaska : U. S. Geol. Survey Bull. 287, pp. 2-4, 1906.
} 
quartz veins were discovered in the vicinity of Auke Lake, north of Juneau, in 1882. This subsequently led to the mines of the Eagle River area, which became notable producers in $1903 .^{5}$ Farther to the north of Juneau in the Berners Bay area, near Sherman Creek, quartz veins carrying gold were discovered in 1887, and some of these furnished noteworthy amounts of gold in $1890 .^{6}$

But the search and finding of lode deposits at this early date was not confined to the Juneau district. Nearly 1,000 miles to the west, on Unga Island, near the tip of the Alaska Peninsula, prospectors had discovered gold-bearing quartz veins, which, by 1891 , began to yield significant amounts of gold and a few years later supplied the ore that made this one of the outstanding lode-gold areas of the Territory. ${ }^{7}$

In the Ketchikan district, in the extreme southern part of southeastern Alaska, copper lodes are reported to have been found and worked in a desultory manner as early as 1870-74, but so far as known the operators did not recover gold from them, though it is now known that almost all the copper ores from that district carry accessory values in gold. The first deposits valuable for their lode gold appear to have been found in this district on Annette Island in 1892, on Gravina Island and on the mainland near Boca de Quadra in 1897, and on Cleveland Peninsula in 1898. By 1898 some of these gold mines, as well as the copper mines on Prince of Wales Island, began to yield annually considerable amounts of lode gold. ${ }^{8}$

Near Snettisham, some 35 miles southeast of Juneau, gold-bearing quartz veins were staked in 1895 , but it was 1899 before they began to yield significant amounts of gold.

In far-off Seward Peninsula silver-bearing lead ores that carried small amounts of gold had been exploited even before 1880, for Petrof records the fact that the Omilak mine, some 125 miles east of Nome, had been known before that date. It was not until the influx of placer-gold miners to Nome in 1899 that search for valuable mineral deposits in the surrounding country had disclosed gold-bearing veins. Although the exact date of their discovery is not now known, the veins in the vicinity of Big Hurrah Creek were among the first to receive serious exploration. This work began in 1901 or 1902 at the Big Hurrah mine, as Collier ${ }^{9}$ records the fact that by 1903 three veins

\footnotetext{
'Knopf, Adolph, The Eagle River region, southeastern Alaska: U. S. Geol. Survey Bull. 502 , p. 8, 1912 .

' Knopf, Adolph, Geology of the Berners Bay region, Alaska: U. S. Geol. Survey Bull. 446, 58 pp., 1911.

7 Atwood, W. W., Geology and mineral resources of parts of the Alaska Peninsula: U. S. Geol. Survey Bull. 467, p. 126, 1911.

8 Brooks, A. H., Preliminary report on the Ketchikan mining district, Alaska: U. S. Geol. Survey Prof. Paper 1, pp. 37-39, 1902.

${ }^{0}$ Collier, A. J., and others, The gold placers of parts of Seward Peninsula, Alaska: U. S. Geol. Survey Bull. 328, pp. 228-232, 1908 .
} 
were in process of development by tunnels and by 1904 a main shaft had reached a depth of 135 feet and active work was in progress.

The constantly widening search for lode-gold deposits in southeastern Alaska finally resulted in 1905 in the discovery of attractive showings in the vicinity of Klag Bay, on the west coast of Chichagof Island, some 60 miles north of Sitka. Developments promptly followed, and in 1906 the first shipments of ore were made from veins in that area that are now part of the property of the Chichagoff Mining Co. ${ }^{10}$

The finding of commercial placers in the Willow Creek area, at the head of Cook Inlet, in 1897 started prospecting in that area that later led to the finding of veins that appeared promising. The first of the lode claims were staked in 1906, and the first mill was built and was in successful operation by the close of 1908 . Since that date lode mining has been constantly in progress, and the camp has been one of the most productive in the Territory. ${ }^{11}$

In the Prince William Sound region the easily accessible areas near the shore had been traversed by prospectors and others almost from the earliest days of the Territory and signs of valuable minerals recognized. In fact, some pits and workings have been found in which stone hammers and other implements indicated that the veins had been partly opened up by the primitive natives, perhaps even before Alaska was known to the whites. Practically all the lode discoveries made by the earlier white prospectors in the Prince William Sound region were deposits in which the principal mineral of value was copper. The more important of the copper lodes were those at Ellamar, ${ }^{12}$ discovered in 1897 and from which the first shipments were made in 1900, and those on Latouche Island, discovered in 1897 but from which no significant shipments of ore were made until 1903 and no regular large shipments begun until 1904. These ${ }^{13}$ and the other copper lodes in the region began to afford appreciable amounts of gold as a byproduct in 1906. The development of mines whose ore was principally valuable for the gold it contained may be considered to date from the discovery in 1909 of the Cliff mine, a few miles west of Valdez. This mine ${ }^{14}$ began to yield considerable gold ore in 1910, and its success greatly stimulated the search for and resulted in the finding of other lode-gold deposits not only through-

\footnotetext{
${ }^{10}$ Knopf, Adolph, The Sitka mining district, Alaska: U. S. Geol. Survey Bull. 504, p. 18,1912 .

11 Capps, s. In., The Willow Croek district, Alaska: U. S. Geol. Survey Bull. 607, pp. 50-51, 1915.

12 Capps, S. R., and Johnson, B. L., The Ellamar district, Alaska : U. S. Geol. Survey Bull. 605 , pp. 13-14, 1915.

${ }^{13}$ Grant, U. S., and Higgins, D. F., Reconnaissance of the geology and mineral resources of Prince William Sound, Alaska: U. S. Geol. Survey Bull, 443, p. 52, 1910.

${ }^{14}$ Brooks, A. H., in Grant, U. S., and Higgins, D. F., idem, pp. 72-75.
} 
out adjacent parts of the Valdez district but also in the more remote parts of the Prince William Sound region.

The extensive placer deposits that had been found in the vicinity of Fairbanks in 1902 naturally attracted many miners to that district, and some of them were active in trying to trace the sources of the placer gold to the veins from which it had been derived. Although the occurrence of gold in bedrock was early recognized, it was not until 1909 that any veins were found which seemed large enough and sufficiently rich to attract attention as workable lodes. A number of such veins at widely separated points in the Fairbanks district seem to have been discovered almost simultaneously, but as the developments on the Rhoads-Hall prospect, on Bedrock Creek, were most actively prosecuted that mine was the earliest to become the most productive and was turning out significant amounts of lode gold by 1910 . By 1912 about 2,000 lode claims had been recorded in the Fairbanks district, and of these about 50 were being more or less actively prospected. ${ }^{15}$

The earliest discovery of lode gold in the Kenai Peninsula appears to date back to 1896 , when rich float was found in the Moose Pass. area. It was 1898 , however, before ledges that were in place were found in the district. Although small amounts of ore were milled in local arrastras by 1904 and small shipments of ore made in 1905 and 1907, it was 1911 before the production of lode gold from the district became significant. ${ }^{16}$ North of Kenai Peninsula proper, but usually for convenience included with it, is the Girdwood district, north of Turnagain Arm. In this area gold-bearing veins were found as early as 1909 and some development work was done on them in 1910 , but it was 1930 before their production of lode gold amounted to more than a few thousand dollars a year. At the southern part of Kenai Peninsula, in the Nuka Bay area, gold-bearing veins were discovered in 1918, though it was 1925 before they began to yield significant amounts of gold. ${ }^{17}$

In the Innoko district, which lies in the southwestern part of the Yukon Valley, lode-gold deposits have long been known to exist in a small area in the hills near the head of Carter Creek, a tributary of Ganes Creek. The exact date of the discovery of the lodes in this area is not known with certainty, but Eakin ${ }^{18}$ states that a mill.

\footnotetext{
${ }^{15}$ Smith, P. S., Lode mining near Fairbanks : U. S. Geol. Survey Bull. 525, pp. 153-154,1913.

${ }^{10}$ Martin, G. C., Johnson, B. L., and Grant, U. S., Geology and mineral resources of: Kenai Peninsula, Alaska : U. S. Geol. Survey Bull. 587, pp. 129-131, 1915.

${ }^{17}$ Capps, S. R., in Smith, P. S., Mineral industry of Alaska in 1936: U. S. Geol. Survey Bull. 897-A, pp. 25-32, 1938.

${ }^{18}$ Eakin, H. M., The Iditarod-Ruby region, Alaska: U. S. Geol. Survey Bull. 578, p. 40, 1914.
}

$306212-41-3$ 
was in operation on the property at the time of his visit in 1912. Mining was done only on a small scale, and only a little gold was produced.

In the Chandalar district, in the northern part of the Yukon Basin, prospecting for lodes has been in progress on a small scale ever since 1907. ${ }^{19}$ Numerous signs of mineralization have been found, and a small stamp mill was hauled in to one of the properties during the winter of 1909-10. The mill, however, has never been used extensively, and the operation has long since been discontinued.

Although lode mining has long been carried on actively in the Copper River region, the principal valuable mineral sought has been copper, which was remarkably free of gold as an accessory mineral, and there has been little lode-gold development. Gold-bearing veins were discovered in the vicinity of Berg Creek in the Kuskulana area as early as 1907, but it was 1918 before developments there had reached such a stage that a mill was installed to treat the ore. ${ }^{20}$ This mill was in operation for only a few years and by 1925 had stopped running. Cessation of work here was apparently caused by the shortage of funds available for development, so that the real worth of the deposit has not been determined.

Gold-bearing veins have long been known in the McKinley Lake area, north of Alaganik, at the mouth of Copper River. Spencer ${ }^{2:}$ noted them during his visit to the region in 1900, and Chapin ${ }^{22}$ gave further information as a result of examinations he made in 1912. In spite of the showings then made, the area has never contributed significant amounts of lode gold.

In the hills northeast of McGrath, in the eastern part of the valley of Kuskokwim River, veins containing mixed sulphides with accessory values in gold and silver were discovered in 1918, and development rapidly pushed forward. By 1920 mining was well under way, and shipments of significant amounts of gold made. A mill was built at one of the properties in 1921, and the quantity of the gold recovered greatly increased. ${ }^{23}$ A high rate of production was maintained through 1924, but after that date, though there has been continuous mining in progress, it has been at a much reduced rate.

10 Maddren, A. G., The Koyukuk-Chandalar region, Alaska : $\dot{U}$. S. Geol. Survey Bull. 532. pp. 75, 111-115, 1913.

${ }^{20}$ Moffit, F. H., and Mertie, J. B., Jr., The Kotsina-Kuskulana district, Alaska : U. S. Geol. Survey Bull..745, pp. 141-146, 1923.

21 Schrader, F. C., and Spencer, A. C., Geology and mineral resources of a portion of the Copper River district, Alaska: U. S. Geol. Survey Special Pub. C, p. 90, 1901.

${ }^{22}$ Chapin, Theodore, The McKinley Lake district: U. S. Geol. Survey Bull. 542, pp. 78-80, 1913.

${ }^{23}$ Martin, G. C., Gold lodes in the upper Kuskokwim region : U. S. Geol. Survey Bull. 722, p. 149, 1922. Brown, J. S., The Nixon Fork country : U. S. Geol. Survey Bull. 783, pp. 127-128, 1926. 
Capps, ${ }^{24}$ who visited the Kantishna district on the northern foothills of the Alaska Range in 1916, states that although up to that time no gold lodes had been brought into production there were many places where exploration was in progress and that although "no single vein has been so far developed as to assure a successful mine, there are nevertheless a number of prospects that are of sufficient promise to warrant thorough exploration and that are likely some day to bring this camp into the list of gold-lode producers." Although that prophecy has not yet come true to more than a limited extent, the camp was productive during the period from 1920 to 1923 and bids fair to make a really significant contribution to the lode-gold production of the Territory shortly.

The successful development of the lode-gold properties at Klag Bay, Chichagof Island, in the Sitka district of southeastern Alaska, referred to on page 170, naturally encouraged prospecting and search through the surrounding country for other workable deposits. As a result, several showings of mineralized vein matter were found at a number of points. Of these finds, however, the most valuable, and now the most extensively developed, were those made at Kimshan Cove, only a short distance north of the large mine at Klag Bay. This later-discovered property, now known as the Hirst-Chichagof mine, made its first significant production in 1922 , since which date it has been in constant operation.

Few gold-bearing veins that have tempted exploitation as lode deposits have been discovered in the Iditarod district. Mertie ${ }^{25}$ noted that in 1922 an attempt was made to mine gold-bearing quartz veins that were found near the head of Glen Gulch. A stamp mill was installed, but the venture did not prove to be profitable and the mill stood idle for many years, until in 1934 and 1935 a new attempt was made to mine the ore. This later trial also proved to be unprofitable, and again the property lies dormant, except for casual prospecting.

In the Nabesna district, near the head of Nabesna River, a tributary of 'Tanana River, the early prospectors found many signs of lode mineralization. Mendenhall and Schrader ${ }^{26}$ note that gold mineralization had been discovered in this district as early as 1899 . No significant amounts of gold, however, were mined or noteworthy developments undertaken until 1906, when a small mill was built on Jacksina Creek. This operation, however, was short lived, for when Moffit ${ }^{2 \tau}$ visited the area in 1908 the mill was standing idle,

\footnotetext{
\$4 Capps, S. R., The Kantishna region, Alaska : U. S. Geol. Survey Bull. 687, pp. 95-106, 1919.

${ }^{25}$ Mertie, J. B., Jr., Mineral deposits of the Ruby-Kuskokwim region : U. S. Geol. Survey Bull. 864-C, pp. 242-243, 1936.

${ }^{20}$ Mendenhall, W. C., and Schrader, F. C., The mineral resources of the Mount Wrangell district, Alaska : U. S. Geol. Survey Prof. Paper 15, pp. 43-45, 1903.

g7 Moffit, F. H., and Knopf, Adolph, Mineral resources of the Nabesna-White River district, Alaska: U. S. Geol. Survey Bull. 417, p. 58, 1910.
} 
though some underground work was in progress. Mining on a large scale in this district therefore cannot be considered to have started until the opening up of the Nabesna Mining Corporation's activities at White Mountain in $1931 .^{28}$

Lode deposits carrying accessory values in gold have long been known to occur in the Bonnifield district, which embraces part of the northern foothills of the Alaska Range. In 1916 some of the betterknown prospects were examined and described by Overbeck, ${ }^{29}$ though at that time none of them had reached a productive stage. In fact the lodes of the district afforded no noteworthy amounts of gold until 1931, when the properties on Eva Creek, a short distance east of Ferry, on the Alaska Railroad, were reopened and a mill built to treat the ore. ${ }^{30}$ Although this property ceased operation after a few years, some lode gold continued to come from other properties in the district. Most of this was from ores whose principal metals of value were silver and lead. ${ }^{31}$

In the Bremner district of the Copper River region, lying south of the Chitina River, lode-gold claims had been staked and some work done on them prior to 1911, when the district was surveyed by a Geological Survey party under the direction of F. H. Moffit, ${ }^{32}$ for he describes several prospects, though he states that none of them had reached the stage of affording significant amounts of gold. This condition continued until 1935, when a mill was built on Golconda Creek, a tributary of the North Fork of Bremner River, and renewed activity in lode developments was shown throughout the adjacent area. ${ }^{33}$ Although even yet the lode production from this district amounts to only a few thousand dollars in gold a year, there are derelopments under way which are planned to step up the production greatly.

The foregoing historical notes cover all of the principal lodegold mining districts of Alaska that have been productive, but it must not be thought that they include all the areas where gold-bearing veins have been reported. For instance, considerable activity at one time was shown in the search for commercial lodes in the Valdez

\footnotetext{
${ }^{28}$ Moffit, F. H., The Suslota Pass district, upper Copper River region, Alaska :-U. S. Geol. Survey Bull. 844-C, pp. 159-161, 1933 ; Recent mineral developments in the Copper River region : U. S. Geol. Survey Bull. 880-B, pp. 103-104, 1937.

${ }^{20}$ Overbeck, R. M., Lode deposits near the Nenana coal field: U. S. Geol. Survey Bull. 662 , pp. $351-362,1918$.

${ }^{30}$ Moffit, F. H., Mining development in the Tatlanika and Totatlanika Basins : U. S. Geol. Survey Bull. 836-D, pp. 339-345, 1933.

${ }^{31}$ Smith, P. S., Mineral industry of Alaska in 1934 : U. S. Geol. Survey Bull. 868-A, p. 24, 1936.

${ }^{32}$ Moffit, F. H., Geology of the Hanagita-Bremner region, Alaska : U. S. Geol. Survey Bull. 576, pp. 49-51, 1914.

${ }^{3}$ Moffit, F. H., Recent mineral developments in the Copper River region: U. S. Geol. Survey Bull. 880-B, pp. 99-102.
} 
Creek district, which lies near the head of Susitna River, some 60 miles east of the station of Cantwell, on the Alaska Railroad. There has been no noteworthy production from any of the veins that have been worked on in a desultory fashion since 1908, but Ross ${ }^{34}$ concluded from his studies in 1931 that it is not unlikely that the area contains several hundred thousand tons of mineralized material whose precious metal content may be worth between $\$ 5$ and $\$ 20$ a ton with some relatively small high-grade bodies. Further examination of this district was made in 1936 by Tuck, ${ }^{35}$ who describes in his report the developments then in progress.

In the Yukon region, in addition to the districts already mentioned in which some productive lode-gold mining thas been in progress, there are known to be gold-bearing veins in the Circle, ${ }^{36}$ Chisana, ${ }^{37}$ Goodpaster, ${ }^{38}$ Hot Springs, ${ }^{39}$ Koyukuk, ${ }^{40}$ and Marshall ${ }^{41}$ districts. Although some development work has been done on these veins, the amount of gold so far recovered from them has been so small that for all practical purposes it may be disregarded. Even in such remote parts of northw'estern Alaska as the Kobuk district ${ }^{42}$ lode-gold mineralization has been found and some attempts made to open up the more promising showings. None of these have yet contributed an appreciable amount of gold to the lode-gold output from Alaska mines.

\section{TOTAL PRODUCTION OF LODE GOLD FROM ALASKA}

The total production of lode gold from Alaska mines to the close of 1937 has been worth $\$ 172,368,000$. The yearly contributions to this great total have fluctuated widely, ranging from the insignificant figure of $\$ 2,000$ in 1880 to $\$ 7,718,000$ in the peak year of 1937 . On figure 6 the record of lode production is graphically shown by years for the period 1882-1937. From this figure can be traced the rather steady increase in production that marked the growth of the in-

\footnotetext{
${ }^{34}$ Ross, C. P., The Valdez Creek mining district, Alaska : U. S. Geol. Survey Bull. 849-I, p. $460,1933$.

${ }^{35}$ Tuck, Ralph, The Valdez Creek mining district in $1936:$ U. S. Geol. Survey Bull. S97-B, pp. 113-122, 1938 .

${ }^{30}$ Capps, S. R., The Chisana-White River district, Alaska: U. S. Geol. Survey Bull. 630, pp. 118-119, 1916.

${ }^{37}$ Smith, P. S., Mineral industry of Alaska in 1936 : U. S. Geol. Survey Bull. S97-A, pp. 22-23, 1938.

${ }^{38}$ Mertie, J. B., Jr., Mineral deposits of the Rampart and Hot Springs districts, Alaska : U. S. Geol. Survey Bull. 844-D, pp. 215-217, 1934.

${ }^{39}$ Maddren, A. G., The Koyukuk-Chandalar region, Alaska: U. S. Geol. Survey Bull. 532, pp. 74-75, 1913.

${ }^{0}$ Smith, P. S., The Noatak-Kobuk region, Alaska: U. S. Geol. Survey Bull. 536, p. 146, 1913.

41 Harrington, G. L., The Anvik-Andreafski region, Alaska : U. S. Geol. Survey Bull. 683, pp. 63-64, 1918.

Smith, P. S., op. cit. (Bull. 536), pp. 144-146.
} 


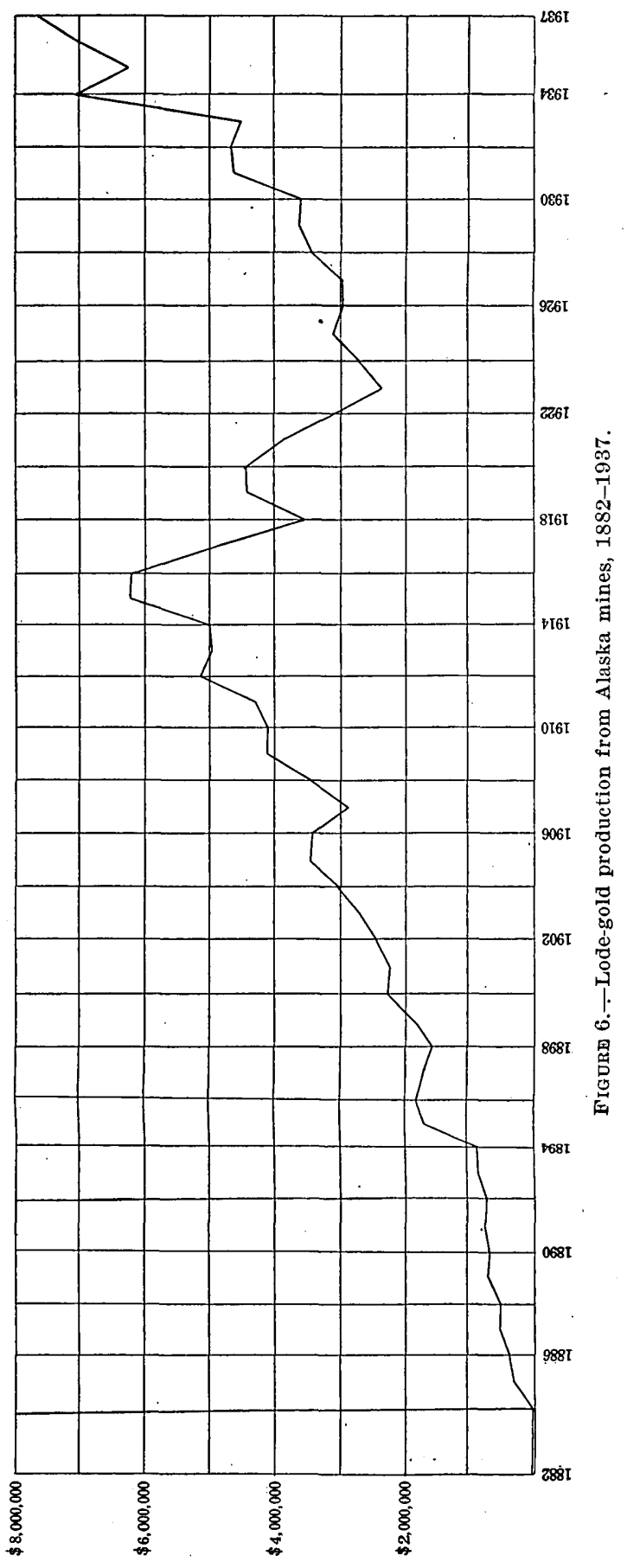


dustry from 1885 , when it first amounted to as much as $\$ 300,000$, until 1915 , when it reached $\$ 6,222,000$. Then ensued a brief halt in the general upward trend, followed shortly after our country's entry into the World War by a rapid decline, which lasted through 1918. A spurt in 1919 and 1920 temporarily checked and reversed the downward trend, so that in those years there was increased production. This improvement was short-lived, for by 1921 the trend was definitely downward, and in 1923 the production reached the lowest point it had touched since 1901. Then followed improvement such that in the succeeding 10 years proeluction had nearly doubled, rising from the low of $\$ 2,377,000$ in 1923 to $\$ 4,549,000$ in 1933 . As was stated on page 163 the price of gold for the years prior to and including 1933 has been computed in this report as worth $\$ 20.67+$ an ounce. This is not strictly in accord with the prices that prevailed during 1933, because there was wide fluctuation in the price set by the Government for newly mined metal, which by the end of that year again became stabilized but at the new price of $\$ 35$ an ounce. The sudden break in the curve showing the change in the value of the production between 1933 and 1934 therefore emphasizes the change in the unit price of the commodity rather than an increase in the quantity of gold produced. In fact, there was a slight falling off in the quantity of lode gold mined in 1934 as compared with 1933. The decrease in the value of the lode-gold output in 1935 is to be attributed directly to strikes and labor difficulties, which caused the suspension of operation at the largest lodegold mine in the Territory for more than a month and a half and a lessened output for some time after work was resumed. Since 1935 the trend of lode production has mounted swiftly, reaching $\$ 7,718,000$ in 1937 , the latest year discussed in this report.

It is obviously impracticable to extrapolate this curve of production far into the future, because many unpredictable elements enter into such surmises. It seems evident, however, from the facts now known that the mines already operating are capable of maintaining the current rate of production for a considerable period. There are also a number of properties in a development stage or that are now being worked only on a small scale that without much delay could materially increase their output. That there are still other deposits as yet undeveloped that will prove to be of equal or even greater worth than some now in production seems hardly open to question. There can be little doubt, therefore, that on the basis of available reserves and present mining installations the lode-gold mining industry of the Territory could maintain for many years an output equal to or exceeding the present high rate of production. 
Whether it will do so necessarily depends on what economic and legislative changes occur by which the price of gold is altered, or how prices or materials, taxes, hours of labor, and related items that enter into mining costs differ from those that now prevail. Mechanical equipment and methods of gold saving will doubtless be improved, so that efficiency of operation will increase and losses of gold be reduced. The effect of both these changes will naturally tend to augment the annual production of lode gold from Alaska mines.

\section{PRODUCTION OF LODE GOLD BY REGIONS}

Certain of the facts shown in more detail in the subsequent tables may be summarized briefly by noting the relative standing of the various Alaska regions with regard to their total production of lode gold as shown in the following table. The rank of the different regions, the value of their total output of lode gold, and the relation, in percentage, that the production of each bears to the total lodegold produced are given.

TaBLe 1.-Lode-gold production of Alasta by regions, for period 1882-1937

\begin{tabular}{|c|c|c|}
\hline Region & $\begin{array}{l}\text { Cotal lode-gol } \\
\text { production }\end{array}$ & $\begin{array}{l}\text { Percent of } \\
\text { total }\end{array}$ \\
\hline $\begin{array}{l}\text { Southeastern Alaska } \\
\text { Cook Inlet-Susitna } \\
\text { Yukon } \\
\text { Prince Wiliam Sound } \\
\text { Southwestern Alaska } \\
\text { Kuskokwim } \\
\text { Seward Peninsula } \\
\text { Copper River } \\
\text { Unidentified }\end{array}$ & $\begin{array}{r}\$ 150,774,995 \\
9,773,839 \\
5,517,843 \\
2,948.823 \\
2,256,323 \\
841,365 \\
193.405 \\
48,594 \\
12,813\end{array}$ & $\begin{array}{r}87.5 \\
5.7 \\
3.2 \\
1.7 \\
1.3 \\
.6\end{array}$ \\
\hline Total & $172,368,000$ & 100.0 \\
\hline
\end{tabular}

The fact that southeastern Alaska outranks all the other regions so greatly is hardly a matter of surprise, because that region is so much more accessible to the settled parts of the States that mining there presents far less serious pioneering problems than in most of the other regions. Juneau, the main center of mining in southeastern Alaska, lies approximately 850 miles in an air line from Seattle and is served by numerous boats sailing weekly on a voyage requiring only 3 days from port to port and on a route which most of the way is in protected waters. As compared with the route from Seattle to Juneau, the route from Seattle to Seward is nearly 450 miles longer in air-line distance, the boat service is much less frequent, and passage across the exposed and often boisterous Pacific Ocean is much more uncomfortable. All of these differences necessarily add to the cost and the difficulties of mining in the more 
remote areas. Mere distance, however, is by no means a factor of paramount importance; because, as indicated by the table, certain of the regions that are far away, such as the Yukon, have.produced more lode gold than certain others that are near, such as the Prince William Sound region. In fact even in southeastern Alaska the largest producing district is in the more northern part, near Juneau, rather than in the more southern part, near Ketchikan, which is about a day's voyage nearer the States.

Although many factors have interacted to cause the production for southeastern Alaska to outstrip so far that of other Alaska lode districts, the richness of the deposits there cannot be considered one of them. In fact, the greater part of the production from the region has come from mines treating extremely low-grade ore that rarely carried as much as $\$ 3$ in gold to the ton and a great deal of which as mined carried less than $\$ 1$ to the ton. The success of these enterprises has, therefore, depended on handling very large amounts of such low-grade material with a maximum of efficiency. This has called for large outlays of capital, broad engineering knowledge, skill, and administrative ability of the highest order to plan wisely and coordinate successfully the countless intricate details that are requisite for smooth accomplishment. That there are other Alaska lode areas where similar strong combinations of large financial resources, technical talent, and business acumen may find outlet for constructive enterprise cannot be doubted. Certainly the obstacles to be overcome in launching such undertakings even now in Alaska are not as great as have confronted some of the large mining ventures in the States and are much less than have been overcome in mining undertakings in many remote parts of the world.

\section{PRODUCTION OF LODE GOLD TO THE CLOSE OF 1905}

As has already been noted, the records of lode gold, as well as of other mineral commodities of Alaska, prior to the close of 1905 are much less definite and exact than those for 1906 and succeeding years. It has therefore proved advisable here to tabulate separately the records of the two periods. In the period prior to 1906 the value of the total production of lode gold from Alaska was $\$ 31,435,000$, an average annual production for the 24 years from 1882 to 1905 , inclusive, of slightly less than $\$ 1,310,000$ a year. In the later period, from 1906 to 1937, inclusive, the total production was $\$ 140,933,000$, or an average annual output worth slightly more than $\$ 4,404,000$ a year, which is about, $3 \frac{1}{3}$ times the rate prior to 1906. 
In tables 2 and 5 , the statistics carried in the column showing the total lode-gold production for each year are based on the tables prepared originally by Brooks ${ }^{43}$ and subsequently used and added to in succeeding publications of the Geological Survey. Unfortunately the original basic material from which the early part of this record was compiled is no longer available, so that it is impossible to review the figures critically. However, such checks as can be made at this late date clearly demonstrate the care with which the estimates were made and the reliability of the figures that have been adopted.

To break down these annual figures for the period prior to 1906 so as to distribute the production among the appropriate districts for each year has not proved possible, and the following table presents the most complete distribution that it now seems practicable to make.

Even as thus organized there are many facts regarding the figures set down that require special explanation as to the reasons for their adoption.

TABLE 2.-Lode-gold production from Alaska by areas, 1882-1905

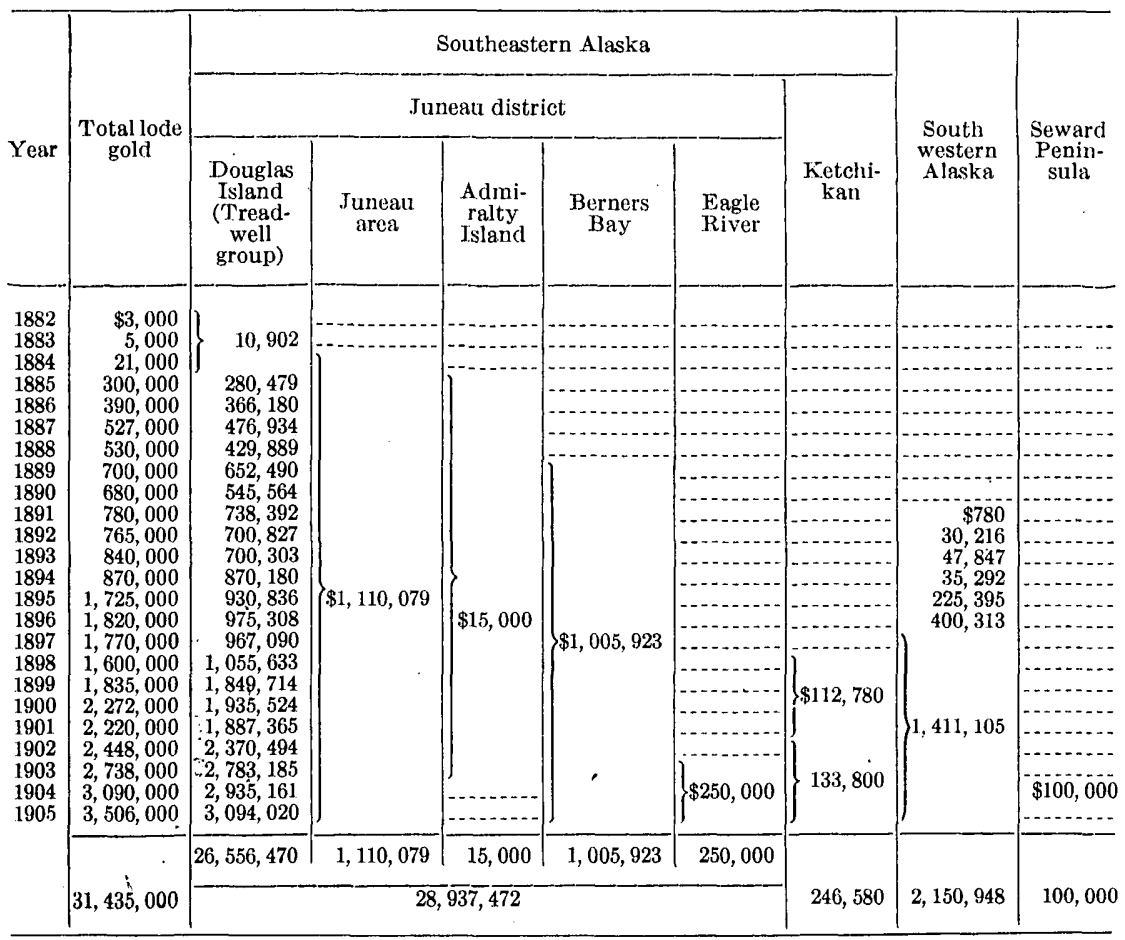

${ }^{43}$ Brooks, A. H., Mineral resources of Alaska in 1923: U, S. Geol. Survey Bull. $773_{1}$ p. $9,1925$. 


\section{SOUTHEASTERN ALASKA}

\section{JUNEAU DISTRICT}

\section{DOUGLAS ISLAND AREA}

In table 2 the production of the area within 50 miles or so of Juneau has been distributed among five main areas, which, for brevity, are called the Douglas Island, Juneau, Admiralty Island, Berners Bay, and Eagle River areas. As is evident, more than 91 percent of the production for the period came from the Douglas Island area. The principal operating company in this area was the Alaska Treadwell Mining Co., which not only had its own properties but had close working agreements with several other companies who owned adjacent properties. In addition to the Treadwell Co. these other affiliated companies were the Alaska United Gold Mining Co., owner of the Ready Bullion and 700 Foot mines, and the Alaska Mexican Gold Mining Co., owner of the Mexican mine. So close was the cooperation between these three large mining companies that, except for accounting purposes, they were often considered a unit and referred to collectively as the Treadwell group. Each of these three companies published annual reports giving in detail excellent records of their progress and production. Unfortunately, however, for the purpose of the present compiler, the records of the Treadwell company for a considerable period subsequent to May 1890 were kept on a fiscal-year basis, which differed greatly from the calendar year. An attempt has been made to recompute the company's record on a calendar-year basis. This has been done on the assumption that as the company's fiscal year was from the first of June of one year to the last of May of the next year, the production for the calendar year was approximately one-half of the reported production for the fiscal year combined with one-half of the reported production for the succeeding year. As this assumption is obviously open to serious criticism, it has seemed best to present separately, in the following table, the company's own statement and the computation made on the above assumption. It will be noted that the discrepancy in the total amounts of the second and third columns is due to the fact that the company's record does not cover that part of 1905 after May 31, whereas in the third column one-half of the company's production for its fiscal year 1906 (i. e., June 1, 1905, to May 31, 1906) has been added. The total production for the fiscal year 1906 was reported to be $\$ 1,902,455$, so that if one-half, or $\$ 951,228$, is added to the total in the second column it would coincide, except for fractional amounts, with the total given in çolumn 3. 
TABLE 3.-Lode-gold production from mines on Douglas Island, 1882-1905

\begin{tabular}{|c|c|c|c|c|c|c|}
\hline Year & $\begin{array}{l}\text { Treadwell } \\
\text { (reported on } \\
\text { company's } \\
\text { fiscal year) } 1\end{array}$ & $\begin{array}{l}\text { Treadwell } \\
\text { (computed } \\
\text { for calendar } \\
\text { year) }\end{array}$ & Mexican & $\begin{array}{l}\text { Ready } \\
\text { Bullion }\end{array}$ & 700 Foot & Total \\
\hline $\begin{array}{l}1882 \\
1883 \\
1884 \\
1886 \\
1887 \\
1888\end{array}$ & $\begin{array}{r}280,479 \\
366,180 \\
476,934 \\
429,889 \\
652,490 \\
160,681 \\
769,765 \\
707,017 \\
694,658 \\
705,948 \\
626,327 \\
782,829 \\
676,064 \\
586,857 \\
677,655 \\
1,153,367 \\
860,736 \\
1,304,720 \\
1,598,963 \\
1,829,508 \\
2,007,842\end{array}$ & $\begin{array}{r}\$ 10,902 \\
280,479 \\
366,180 \\
476,934 \\
429,889 \\
652,490 \\
545,564 \\
738,392 \\
700,827 \\
700,303 \\
666,138 \\
704,578 \\
729,446 \\
631,461 \\
632,255 \\
915,511 \\
1,007,051 \\
1,082,728 \\
1,451,842 \\
1,714,235 \\
1,918,675 \\
1,955,148\end{array}$ & $\begin{array}{r} \\
204,042 \\
226,258 \\
245,862 \\
335,629 \\
375,882 \\
347,415 \\
315,005 \\
339,452 \\
426,732 \\
699,385 \\
661,174 \\
700,737\end{array}$ & \begin{tabular}{|r|} 
\\
\end{tabular} & $\begin{array}{r}\ldots \\
\\
\\
\\
\hdashline\end{array}$ & $\begin{array}{r}280,479 \\
366,180 \\
476,934 \\
429,889 \\
652,490 \\
545,564 \\
738,392 \\
700,827 \\
700,303 \\
870,180 \\
930,836 \\
975,308 \\
967,090 \\
1,055,633 \\
1,849,714 \\
1,935,524 \\
1,887,365 \\
2,370,494 \\
2,783,185 \\
2,935,161 \\
3,094,020\end{array}$ \\
\hline & $17,359,811$ & $18,311,028$ & $4,877,573$ & $2,662,386$ & 705,483 & $26,556,470$ \\
\hline
\end{tabular}

1 The Treadwell Co.'s report for 1890 covers only the period from Jan. 1 to May 31, 1890. Its reports for each of the years, 1891 to 1905 , inclusive, include from June 1 of the preceding calendar year to May 31 of the calendar year stated; thus its record for the fiscal year 1891 includes the period from June 1, 1890, to May 31,1891 , and so on for each succeeding year.

In this same table are shown the production records for the Mexican, Ready Bullion, and 700 Foot mines, which began significant production in 1894, 1898 , and 1899, respectively. As these other mining companies reported their operations on a fiscal-year basis that did not materially differ from the calendar year, their records have been given here exactly as published in their annual reports, except for the omission of the cents carried in the original reports. The totals for all the large producing companies in the Douglas Island area have been determined by disregarding the figures shown in column 2 of the table and combining those in columns $3,4,5$, and 6 for the appropriate years, and these totals are the ones that have been set down in the appropriate column in table 2 (p. 180). Because of the method here used in determining the Treadwell production for the calendar year, the totals given here differ from those that have been given in certain other reports, notably Geological Survey Bulletin $287^{44}$ and Engineering and Mining Journal. ${ }^{45}$ In both of those reports the Treadwell figures are given on the company's fiscal-year basis, and in the Spencer report no production is shown for either the Mexican or Ready Bullion mines in 1905 .

\section{JUNEAU AREA}

Estimates as to the production of lode gold from the country immediately adjacent to and east of Juneau, here called the Juneau area,

4 Spencer, A. C., The Juneau gold belt, Alaska : U. S. Geol. Survey Bull. 287, p. 95, 1906.

${ }^{45}$ Mining at Juneau in 1915 : Eng. and Min. Jour., vol. 101, No. 3, p. 135, 1916. 
involve considerable uncertainty because of the various changes in ownership that have occurred whereby there has been duplication or: overlap of some of the early reports and the distinction between lode and placer gold has not always been made. Thus Spencer, ${ }^{46}$ on extremely indefinite information, estimated that the mines in the Gold Creek area up to 1904 had probably produced about $\$ 2,250,000$ in gold, of which about $\$ 1,000,000$ was from lode mines. This estimate checks fairly closely with certain records from other sources. For instance, Spencer states that the Ebner mine on Gold Creek had produced gold to the value of approximately $\$ 575,000$ up to the end of 1902 , and in 1903 had produced lode gold worth in exciess of $\$ 25,000$, or a total of $\$ 600,000$. In its annual reports the Alaska Juneau, which has operated the only other large lode-gold property on Gold Creek, combines all of its production from 1893 to 1913, inclusive, in one item, which is given as $\$ 707,730$. If from this total is subtracted the amount recorded in the reports available in the Geological Survey for eich of the years 1906 to 1913, it is found that the remainder, representing the production from 1893 to 1905 , inclusive, is $\$ 510,079$. However, some doubt is felt as to just what area is included in this company's early record, because the company was not organized until $1897,{ }^{47}$ so that the earlier records of production for the claims it later acquired were assembled from various sources, which are no longer available for analysis. Unless it includes more than the production from its own restricted holdings, the amount seems excessive, because up to 1896 only a small 5-stamp mill was in operation on its property, and the mill was running only during the summer monthș. In 1896 a 30 stamp mill was built, which also was run only during the summer. The detailed records of the mill for the period frôm 1896 to 1900 , inclusive, are not now available, but the following table from the company's annual report for $1923{ }^{48}$ gives certain information for the 5 years 1901 to 1905 , inclusive:

TABLE 4.-Lode-gold production of Alaska Juneau mine, 1901-5

\begin{tabular}{|c|c|c|c|c|}
\hline Year & $\begin{array}{c}\text { Days in } \\
\text { operation }\end{array}$ & $\begin{array}{l}\text { Tons mined } \\
\text { per day }\end{array}$ & $\begin{array}{l}\text { Gold recov- } \\
\text { ered per } \\
\text { ton mined }\end{array}$ & $\begin{array}{l}\text { Computed } \\
\text { production } 1\end{array}$ \\
\hline $1902,1901,1904$ & $\begin{array}{r}123 \\
155 \\
158 \\
187 \\
199\end{array}$ & $\begin{array}{l}110 \\
118 \\
114 \\
127 \\
127\end{array}$ & $\begin{array}{r}\$ 1.52 \\
1.86 \\
1.62 \\
1.59 \\
1.27\end{array}$ & $\begin{array}{r}\$ 20,566 \\
34,019 \\
29,179 \\
37,761 \\
32,097\end{array}$ \\
\hline Total ... & . & | & - & 153,622 \\
\hline
\end{tabular}

1 Computed by writer on basis of figures in preceding columns.

${ }^{40}$ Spencer, A. C., op. cit., pp. 59-60.

¿ Bradley, P. R., History, organization, and outlook [of the Alaska Juneau Enterprise] : Eng. and Min. Jour., vol. 133, p. 460, 1932.

${ }^{48}$ Alaska Juneau Gold Mining Co. 9th Ann. Rept., for the year endéd Dec. 31, 1923, p. 15, 1924. 
It seems unlikely that the production for the 5 years, 1896-1900, should have exceeded that for the 5 years $1901-05$, and certainly it is extremely improbable that during the 3 years $1893-95$, when the enterprise was starting and only the 5-stamp mill was in operation, the output should have been more than a few thousand dollars a year. It is believed, therefore, that something like $\$ 200,000$, now attributed to the Alaska Juneau property, came from other properties that Spencer included in his tabulation as "Mines south of Juneau." If this interpretation is erroneous and if the total yearly production of the Territory is correct, as stated, it follows that any deficiency in the estimate for the production of the Juneau area can be made up only by deduction from the figures set down in the columns for the other areas. Such deductions do not appear justified from the facts now at hand, and the total lode-gold production from the Juneau area to the close of 1905 is estimated to have been approximately $\$ 1,110,000$. However, in order that it may be clearly evident as to how this figure was arrived at, it may be stated that it is the sum of the Spencer estimate of $\$ 600,000$, for the production from the Ebner property, and $\$ 510,079$. The latter figure is the difference between the published combined record of the Alaska Juneau Gold Mining Co. for the years 1893 to 1913, inclusive, and the Survey's record of the production of that company for the years 1906 to 1913, inclusive.

\section{ADMIRALTY ISLAND AREA}

The discovery of gold-bearing lodes in the Admiralty Island area dates back to 1885 . According to Wright, ${ }^{49}$ however, the total production up to the close of 1903 did not exceed $\$ 15,000$. This seems an extremely conservative estimate, for Becker ${ }^{50}$ had stated that the production in 1896 of the Boston \& Alaska Co., which was operating a mine near Funter Bay, was $\$ 16,000$. Evidently analysis of all the information available to Wright at the later period when his report was prepared caused him to adopt the smaller figure he published. As no later information has been found that would modify his conclusion, his estimate of production for the area has been adopted in the present report.

\section{BERNERS BAY AREA}

The Berners Bay area embraces the northwestern extremity of what is often locally referred to as the Juneau gold belt. It is situated some 40 miles north of Juneau, on the eastern shore of Lynn Canal.

\footnotetext{
${ }^{40}$ Wright, C. W., A reconnaissance of Admiralty Island, Alaska: U. S. Geol. Survey Bull. 287, p. 147, 1906.

${ }^{50}$ Becker, G. F., Reconnaissance of the gold fuelds of southern Alaska : U. Ș. Geol. Survey 18th Ann. Rept., pt. 3, p. 78, 1897.
} 
The special mining features of the district are described by Knopf, ${ }^{51}$ from whose report the following notes are abstracted. Gold-bearing veins were discovered in the district in 1886-87, and by 1890 a city had been established on Sherman Creek, which was called Seward City. Between 1886 and 1890 five stamp mills aggregating eighty stamps were set up and were in more or less continuous operation. Litigation caused cessation of operations of certain of the larger properties during the years 1905 to 1909 . Knopf estimated that the total production of the district, up to the close of 1909, was approximately $\$ 1,100,000$. Deducting from that figure the production shown by the Geological Survey records for the years 1906-8, inclusive, the production of lode gold for the district up to 1905 is determined to have been worth $\$ 1,005,923$-the figure that has been entered in the appropriate columns of tables 2 and 5 . This production came almost entirely from the Comet and Jualin mines, which were opened up in 1890 and 1896, respectively. The largest single year's production was that in 1895 from the Comet, which exceeded $\$ 200,000 .^{52}$ Knopf ${ }^{\dot{5} 3}$ further states that the Comet produced 50,000 tons of ore averaging at least $\$ 9.20$ to the ton. At this rate its output of lode gold would have been worth $\$ 460,000$.

\section{EAGLE RIVER AREA}

In the Eagle River area, which lies north of Juneau and south of Berners Bay, prospecting for gold-bearing lodes was undertaken as early as 1882 on Windfall and Montana Creeks, but no noteworthy production came from the area until the discovery of the veins on the property of the Eagle River mine in 1902. A mill was built to handle the ore from this mine in 1903 and considerable mining carried on. The Wrights ${ }^{54}$ state that the total production of the Eagle River mine to the close of 1905 was $\$ 250,000$. Knopf ${ }^{55}$ states that except for a few thousand dollars the entire production of the district came from this one mine. The Wrights' estimate of $\$ 250,000$ for the total production of the Eagle River mine to the close of 1905 is therefore accepted as the correct figure for the entire area, and that amount has been entered in the appropriate columns in tables 2 and 5 , and attributed to the years 1903 to 1905 , inclusive.

\footnotetext{
${ }^{61}$ Knopf, Adolph, Geology of the Berners Bay region, Alaska: U. S. Geol. Survey Bull. 446, 58 pp. (especially p. 8), 1911.

52 See also Becker, G. F., op. cit., p. 77, who conftrms that figure and states that the Comet in 1896 , according to the Bureau of the Mint, produced $\$ 125,000$.

53 Knopf, Adolph, op. cit., p. 31.

64 Wright, F. E. and C. W., Lode mining in southeastern Alaska: U. S. Geol. Survey Bull. 284, p. 35, 1906.

56 Knopf, Adolph, The Eagle River region, souṭeastern Aḷaska; U, S. Geol, Sụrvey Buḷ, 502,60 pp. (especially pp. $8,9,44,45$ ) , 1912 .
} 


\section{KETCHIKAN DISTRICT}

Gold derived from lodes in the Ketchikan district comes from two distinct types of deposits; namely, from those in which the gold is the principal mineral of value and from those which are mainly valuable for their copper content but which carry significant amounts of gold that is recovered as a byproduct. Brooks estimated that the production from the lodes that were mainly valuable for their gold for the period from 1898 to 1901 was $\$ 100,000$. The Wrights, ${ }^{56}$ who later studied the region, accepted Brooks' ${ }^{57}$ estimate for the period prior to 1902 and estimated the production from the gold lodes for the years 1902 to 1906 , inclusive, as $\$ 120,000$. If from the estimate of the Wrights is subtracted the amount shown by the Geological Survey records as produced in 1906 , namely, $\$ 20,570$, the combined estimates of Brooks and the Wrights to the close of 1905 for the gold-lodes in the Ketchikan district becomes $\$ 199,430$. In the same report the Wrights' estimate of the recovery of gold from the copper ores during the period 1901 to 1906 , inclusive, was $\$ 110,000$. As they state the production from this source for the year 1906 was $\$ 62,851$, it follows that the production for the period to the close of 1905 was $\$ 47,150$. This makes the total lode-gold production from the district, up to the end of $1905, \$ 246,580$. In the appropriate column in table 2 this total has been distributed as $\$ 112,780$ for the period 1898 to 1901 and $\$ 133,800$ for the period 1903 to 1905 .

\section{SOUTHWESTERN ALASKA}

The early development of gold mining in southwestern Alaska is quite fully recorded by Becker ${ }^{58}$ in his account of the Apollo Consolidated mine, on Unga Island. From this record the statistics of production for the years 1891 to 1896 , inclusive, shown in table 2, are taken. The records of the subsequent work to the close of 1905 are extremely inadequate. Martin, ${ }^{59}$ who visited the mine in 1904, stated that the total production to that date had been between $\$ 2,000,000$ and $\$ 3,000,000$. Atwood, ${ }^{60}$ who visited the region in 1908, stated that

\footnotetext{
56 Wright, F. E. and C. W., The Ketchikan and Wrangell mining districts, Alaska ; U. S. Geol. Survey Bull, 347, pp. 19-20, 1908.

${ }^{67}$ Brooks, A. H., Preliminary report on the Ketchikan mining district, Alaska; U. S. Geol. Survey Prof. Paper 1, p. 39, 1902.

ธ8 Becker, G. F., Reconnaissance of the gold fields of southern Alaska: U. S. Geol. Survey 18th Ann. Rept:, pt. 3, pp. 12, 83-85, 1897.

${ }^{50}$ Martin, G. C., Gold deposits of the Shumagin Islands : U. S. Geol. Survey Bull. 259, p. $100,1906$.

Atwood, W. W., Geology and mineral resources of parts of the Alaska Peninsula: U. S. Geol. Survey Bull. 467, pp. 125-127, 1911.
} 


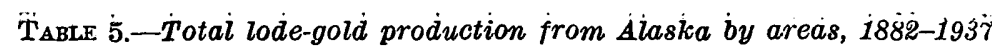

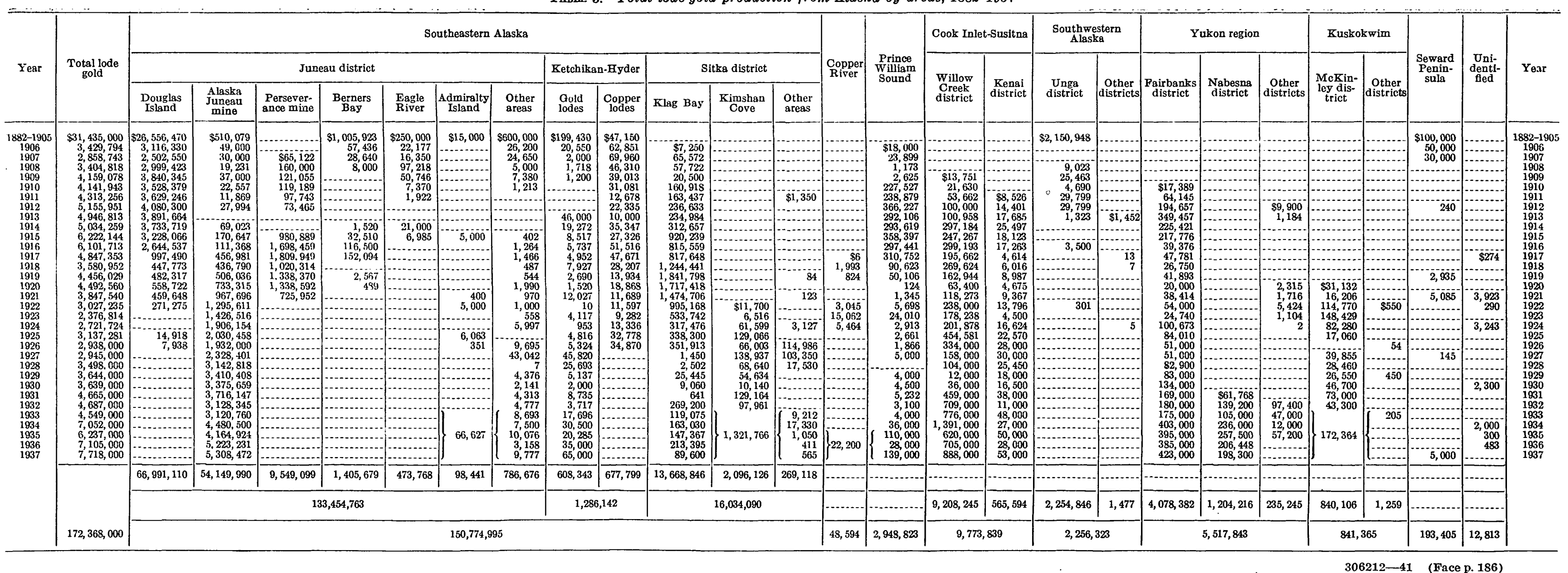


productive work was discontinued at the mine at the close of 1904 and was not resumed until 1908. In view of the lack of definite information as to the production from this region during the years 1897 to 1904, inclusive, the writer has been driven to attribute to this mine for that period the difference between the total Alaska lode production as recorded in column 2 of table 2 and the sum of the totals of all the other columns and the specific records for the earlier years of this region. On this basis it is assumed that the total production from the Unga Island mines for the years 1897 to 1904, inclusive, was $\$ 1,411,105$, and the total for that region for the period from 1891 to 1905 , inclusive, was $\$ 2,150,948$. Although admittedly these estimates are based on less dependable data than those for the other areas and are far less accurate than is desired, it seems that they are probably of the right order of magnitude. It will be seen that they approach the minimum rather than the maximum estimate made by Martin.

\section{SEWARD PENINSULA}

Lode mining in Seward Peninsula has never reached a very productive stage, and in the period prior to 1906 it was practically confined to one mine in the Solomon district, east of Nome. The ore deposit at this place appears to have been discovered about 1900, but little active production took place until 1903, when a 20 -stamp mill was built and considerable underground development carried on. Smith ${ }^{61}$ gave a general description of the property as a result of his studies there in 1907, but did not furnish any specific figures as to the amount of gold produced. Judging from the size of the excavation that had been made and the apparent tenor of the ore, it seems probable that the production for the 3 years, 1903 to 1905, inclusive, was approximately $\$ 100,000$, and that figure has been adopted for use in table 2 of the present report.

\section{SUMMARY}

Summarizing the results of the foregoing analysis of the lode-gold production from Alaska mines prior to 1906, it has been shown that the total production is estimated to have been $\$ 31,435,000$. Of this amount over $\$ 29,100,000$ came from mines in southeastern Alaska, and of these, those on Douglas Island produced gold to the value of more than $\$ 26,500,000$ :

\footnotetext{
61 Smith, P. S., Geology and mineral resources of the Solomon and Casadepaga quadrangles, Seward Peninsula, Alaska: U. S. Geol. Survey Bull. 433, pp. 139-150, 1910.
} 


\section{PRODUCTION OF LODE GOLD SINCE 1905}

\section{GENERAL STATEMENT}

Subsequent to the close of 1905 the records of the mineral production from Alaska mines are much more definite and exact, because the collection of the data became more systematized by the Geological Survey and practically all of these records are still extant. 'The records, however, are by no means perfect, because not all producers send in as complete information regarding their work as is desired, and doubtless misinterpretations are made in the course of editing the reports received. It is, however, the constant aim of the Geological Survey to improve its methods for the preparation of its current statistics, and it is to be hoped that the mine operators will feel an interest in seeing to it that their records filed with the Geological Survey are complete and accurate.

The available records from all of the Alaska lode-gold camps for the period 1906 to 1937, as far as seems desirable, have been tabulated by years and for the various regions, districts, and areas in table 5. In this table have also been included the figures for the total lode-gold production prior to 1906, which are identical with the totals given in table 2.

In the main the table speaks for itself, its principal purpose being to bring together in compact form the available records for the past 55 years so that they may be inspected readily. Some matters that are less patent but that seem worth mention in connection with the table will be discussed in a brief review of each of the areas, given in the same order as that in the table.

\section{SOUTHEASTERN ALASKA}

JUNEAU DISTRICT

DOUGLAS ISLAND AREA

The mines of the Douglas Island area continued to maintain the high rate of production they had reached in earlier years until in April 1917, when a disastrous cave-in occurred and the nearby sea water broke into the mine and in a few hours caused the virtual abandonment of the principal workings at the Treadwell and adjacent properties, except the Ready Bullion mine. The Ready Bullion mine kept up production at about a normal rate until 1922, when it too closed down. The shutting down of this great group of mines was a momentous event in the history of Alaska mining. During their life these mines had turned out lode gold to the value of approximately $\$ 67,000,000$, or about 39 percent of all the lode gold that had been produced up to the end of 1937 . Of this group the Treadwell mine 
was easily the largest producer, with an output worth over $\$ 39,800$ 000 ; the Mexican and Ready Bullion mines stood next in order, with productions of $\$ 11,600,000$, and $\$ 10,600,000$, respectively; and the 700 Foot mine was the smallest, with a production of 'somewhat over $\$ 5,000,000$.

Before leaving the record of the production of the group of mines on Douglas Island, as here set down, it perhaps should be noted that the figures given do not correspond exactly with those given in the annual reports of the several companies. Thus, the companies' published reports show a production for the period 1882 to 1918 totaling $\$ 65,473,466$, whereas the Survey's record for the period 1906 to 1918, supplemented by the record already discussed (p. 182), for the period 1882 to 1905 , inclusive, is $\$ 65,196,292$, or about $\$ 277,000$ less. Probably this difference is to be accounted for by the inexact method necessarily used by the writer in computing the production prior to 1906 and by the probability that some of the gold recorded by the Geological Survey as having been produced subsequent to 1918, amounting to $\$ 1,794,818$, may have been included by the companies in their reports as having been produced in earlier years. No reports published by the companies giving details for the years subsequent to 1918 have been available to the Geological Survey, so that there has been no opportunity to check the records since that date. Regrettable as it is that the results obtained from the two sources do not check more closely, it should be realized that the discrepancy in the two records, covering a period of 45 years, is small, being only 0.4 percent of the total amount involved.

\section{ALASKA JUNEAU MINE}

In the column showing the record of the Alaska Juneau mine it will be noted that the production of lode gold from 1906 to the end of 1912 was at an annual rate of aboit $\$ 30,000$. This marked the period during which the company was operating a mill with 30 stamps. In 1913 there was no production, as a new mill was in process of construction. This new mill was a pilot mill designed to test out extensive changes in milling practice that were proposed, so as to gain the necessary information for the planuing of a large mill that would effect notable economies. The use of the pilot mill began in 1914 and was continued until the end of 1916. Meanwhile a new mill, which was expected to treat 8,000 tons a day, was in course of construction and was put into operation early in 1917 . Unfortunately the mill was unable to maintain a capacity of much more than one quarter of the expected tonnage, so that after various unsuccessful attempts to remedy the defects the mill was thoroughly reorganized and in 1920 began operation. The beneficial effect of 
these alterations on the production became immediately evident; by 1922 the annual production passed the $\$ 1,000,000$ mark and the tonnage handled was stepped up to an average of 6,400 tons a day, the milling costs at the same time being reduced to about 26 cents a ton. Subsequent improvements in the mine and the mill have resulted in further increasing the tonnage handled and reducing the operating costs. Thus in the annual report for $1937{ }^{62 \cdot}$ it is stated that in that year $4,442,760$ tons of ore were trammed to the mill, or an average of nearly 12,200 tons a day, and that the average cost of milling for each ton of ore trammed was 24.5 cents. This enterprise has long been one of the notable mining developments of the world, and the success in handling enormous amounts of low-grade ore cheaply has been biought about through the application of the most advanced technical methods and administrative acumen. The marvel of the accomplishment becomes all the more striking.when it is realized that, according to the company's report for 1937, the gold content of all the rock from mine to mill during the entire period that mining has been in progress, and in course of which more than $35,000,000$ tons of ore were finemilled and 30,000,000 tons of coarse tailings rejected, has averaged only 0.0453 ounce to the ton. This quantity of gold at the old unit price would be worth about 93.5 cents, or at the new price aiont $\$ 1.585$.

In comparing the total value of the gold production of the Alaska Juneau mine as set down in table 5 with that published by the company in its latest annual report, there is a difference of about $\$ 700,000$. In referring to this difference it should be uniderstood that the statements relate solely to the production of gold, for it is well known that accessory values of other metals, such as silver and lead, from the ores mined by this company have been worth about $\$ 2,600,000$ in addition to the gold content. In the main this difference is due to the fact that in the company's report the gold production for 1933 is stated as the actual amount received by the company, whereas the Geological Survey figures are computed on the old standard value of $\$ 20.67$ an ounce: Computing the unit value of the gold by dividing the total value, as stated by the company, by the quantity produced, indicates that the company received about $\$ 25.36$ an ounce for the gold it produced in 1933 . Therefore practically all the difference between the two sets of figures would disappear if both records for 1933 had been computed on a uniform basis. In fact these two sets of figures would then agree within about $\$ 15,000$, which can well be accounted for by minor differences in computation arising from variations in the number of decimal places to which some of the computations were carried or the rounding off of some of

\footnotetext{
2. Alaska Juneau Gold Mining Co. 23d Annual Rept., for the year ended Dec. 31, 1937, 16 pp., 1938.
} 
the items. Although recognizing the fact that the company's figures undoubtedly reflect more accurately the amount received by it for its gold in 1933, it has seemed desirable to use here the amount resulting from the Survey's method of computation. In this way the fluctuations that took place in the price of gold in 1933 are disregarded, and the production of all Alaska lode-gold mines are computed on a uniform basis, uninfluenced by favorable or adverse conditions that may have prevailed when various individual lots of gold were marketed.

\section{PERSEVERANCE MINE}

The figures in table 5 set down under the column headed "Perseverance mine" do not fully reflect the production from this property, which has at different times been operated by several different owners. It was one of the early mines opened up in the area near Juneau, and its production up to the end of 1905 has been grouped with that of other mines in the Juneau area. In 1906 the milling facilities were enlarged, so that by the end of 1907 there were 100 stamps available and the production for the next few years was greatly increased. ${ }^{63}$ Indeed the operations were so successful that a still larger development seemed warranted, and new financing and management led to the construction of a mill designed to handle 6,000 tons of ore a day and to the further opening up of the mine. These additional improvements were successfully completed in 1914, and their effect was reflected in the great jump in production shown in 1915. Then ensued a period of 7 years during which the value of the gold won from this property averaged considerably more than $\$ 1,000,000$ a year. Unfortunately mounting costs brought about by the World War and its aftermath, coupled with the fact that the tenor of the ore proved lower than the preliminary tests had indicated it would be, ultimately led to suspension of operations in 1921. For a number of years thereafter the mine lay idle, but in $1934{ }^{64}$ negotiations were carried through whereby the property was acquired by the Alaska Juneau Gold Mining Co., and since that time active development has been in progress to unify the operations of the two mines. Since 1936 some ore has been taken each year from the former Perseverance property by the new owners, but its gold has not been credited separately in the accompanying tables but has been considered as an integral part of the production of the Alaska Juneau property. How important a contribution this supplementary ore from the old Perseverance property has been is shown by the 1937 statement of the

\footnotetext{
${ }^{63}$ Wright, C. W., Lode mining in southeastern Alaska, 1907 : U. S. Geol. Survey Bull. 845, p. $88,1908$.

os Smith, P. S., Mineral industry of Alaska in 1934 : U. S. Gool. Survey Bull. 868, pp. 14-15, 1937.
} 
Alaska Juneau Gold Mining Co. ${ }^{65}$ that since the old mine came under its new ownership it had furnished nearly 743,000 tons of ore, which had an average gold assay of 0.0527 ounce to the ton. At $\$ 35$ an ounce for gold, this ore carried gold worth nearly $\$ 1,370,000$.

\section{BERNERS BAY AREA}

The record of the lode-gold production from the Berners Bay area shows a gradual dwindling from the high rate of production that prevailed prior to 1906 until productive mining almost ceased by the close of 1907 , and the camp was practically abandoned until 1915. Late in 1914, through new financing and management, reopening of the property of the Berners Mining Co. was undertaken, and for a few years the production was greatly increased. By 1918 this activity had subsided, and since that time only negligible amounts of gold, some of which doubtless has been included in the column headed "Other areas," in the Juneau district, have been produced by mines in this area. With the great increase in 1933-34 in the unit price of gold, renewed activity was shown in again establishing the mines of this area on a producing basis. Much preparatory work was done in constructing roads and making other surface improvements, as well as in carrying on underground developments, but before the mines had been brought into production the work was stopped, owing, it was said, to the Terrritorial tax of 3 percent that was levied in 1936 on the gross production of all gold in excess of $\$ 10,000$. This new tax, the owners felt, would have militated too heavily against the success of the new enterprise.

\section{EAGLE RIVER AREA}

In the Eagle River area the high rate of production initiated in 1904 and 1905 soon dropped off and by 1915 had become negligible. Knopf, ${ }^{66}$ who visited the area in 1910 , in discussing the history of the district subsequent to 1905 , stated :

The development since then has been far less rapid than was expected at that time. Many causes have continued to retard the progress of the mining industry, among them litigation and inflated valuation, but the principal cause is the low grade of the ores. Large capital is necessary to open the properties, and investors usually demand more thorough development of the ore bodies than so far has been made at most places.

\section{ADMIRALTY ISLAND AREA}

Owing to the fact that practically all the lode-gold production from Admiralty Island of late years has come from a single mine at Hawk Inlet, the lode-gold production of the area for 1933 to

\footnotetext{
${ }^{65}$ Alaska Juneau Gold Mining Co. 23d Ann. .Rept., for the year ended Dec. 31, 1937, table on p. 11, 1938.

${ }^{68}$ Knopf, Adolph, The Eagle River region, southeastern Alaska: U. S. Geol. Survey Bull. 502, pp. 8-9, 1912.
} 
1937, inclusive, has not been tabulated by separate years but has been stated as a single amount. It should also be noted that the source of some production that probably came from mines on Admiralty Island has not been specifically identified and therefore has been carried in the column headed "Other areas" in the Juneau district in table 5 .

\section{OTHER AREAS}

In the column headed "Other areas" in the Juneau district have been entered the records of lode gold derived from mines in areas not specifically listed elsewhere in the table, as well as some gold whose precise source has not been specifically identified closer than that it came from the Juneau district. It is evident that by far the larger part of the gold thus recorded was produced prior to 1906 and, as has already been stated, came mainly from the country immediately adjacent to and east of Juneau. Some lode gold still continues to come from small producers in the near vicinity of Juneau, but most of the lode gold that is now produced and is specially. identified as having come from other areas, comes from more distant parts of the district. For example, in the vicinity of Windham Bay, some 60 miles south of Juneau, considerable mining has been done on a number of claims at the head of the bay and on Shuck River, a tributary from the south. These properties have experienced many changes in ownership, and years of activity and inactivity have ensued. A few miles farther north, near Sumdum, are lodes that at one time supported a considerable industry and that even lately have been the scene of mining development. Still farther north in the vicinity of Snettisham, which is only about 35 miles south of Juneau, lode mining has been in progress at intervals from almost the earliest days of mining in the district, though the total production has been small. Prospecting of lode deposits near Taku Inlet, close to the international boundary disclosed veins which, during 1928 and 1929, were subjected to extensive tests. Unfortunately the results obtained from those deposits found on the Alaska side of the boundary line were not such as to lead to productive mining of any of them. ${ }^{67}$ Small showings of mineralization have also been found at numerous other places within the Juneau district. ${ }^{68}$. In fact, it is but little exaggeration to say that signs of mineralization are almost universally present there, though of course most of them are not such as to warrant an attempt at extensive development.

\footnotetext{
or Smith, P. S., Mineral industry of Alaska in 1928: U. S. Geol. Survey Bull. 813, pu. 13-14, 1930.

${ }^{6}$ Smith, P. S., Mineral industry of Alaska in 1929 : U. S. Geol. Survey Bull. 824, p. 14, 1032.
} 
The Ketchikan district, as that term is used in this report, includes all the extreme southern part of southeastern Alaska and embraces such widely separated areas as the Hyder area, at the head of Portland Canal, and the Wrangell area, as well as the mines of Prince of Wales Island and other areas that lie closer to Ketchikan. For many years while copper mining was active at the mines near Kasaan, on the east coast of Prince of Wales Island, it was desirable to draw a distinction between the gold that was derived from their ores and that which came from ores more distinctly valuable for their gold content. At best this distinction was more or less an artificial one and became of no practical moment when the copper mining industry, as such, waned and finally ceased. So, since 1926 the value of the gold from both kinds of ore has been combined in the tabulation. It should be realized, however, that even currently some copper is obtained from ores in this district whose principal value lies in their gold or platinum metals content.

The early history of the mineral deposits of the Ketchikan and Wrangell areas, as well as details concerning the various deposits up to the close of 1906 , was quite fully described by the Wrights. ${ }^{.5}$ That record has been supplemented by succeeding annual volumes on the mineral industry of Alaska and a general comprehensive digest of the geologic relationships in a report by Buddington and Chapin. ${ }^{70}$

The Hyder district, which has been included here with the Ketchikan district, had been known to contain showings of mineralization even as early as 1901. Little active prospecting of those showings had been done, however, until after 1918, when the discovery of the now famous Premier deposits, only a short distance away in Canadian territory, was followed by a rush of prospectors and miners into the general region. The height of gold production from the Hyder district took place in 1926 and 1927, but the flurry soon died down, and in later years only negligible amounts of lode development have been in progress. The geology and ore deposits of the area have been described by Buddington. ${ }^{11}$

Lode-gold mining was never.carried on actively in the part of the district near Wrangell, though the Wrights ${ }^{72}$ note that in 19001901 considerable prospecting was done on gold and copper deposits on Woewodski Island, some 25 miles west of the town of Wrangell.

\footnotetext{
${ }^{6}$ Wright, F. E. and C. W., The Ketchikan and Wrangell mining districts, Alaska: U. S. Geol. Survey Bull. 347, 201 pp., 1908.

${ }^{70}$ Buddington, A. F., and Chapin, Theodore, Geology and mineral deposits of southeastern Alaska : U. S. Geol. Survey Bull. 800, 398 pp., 1929.

71 Buddington, A. F., Geology of Fyder and vicinity : U. S. Geol. Survey Bull. 807, 124 pp., 1929.

72 Wright, F. E. and C. W., op. cit., p. 19.
} 
At that time a large stamp mill was built on the property and numerous surface improvements made, but operations there were soon suspended. Revival of mining activity took place again in 1915, but though prospecting on a small scale has been done during each year since it has not contributed any noteworthy amount of gold.

\section{SITKA DISTRICT}

The Alaska district having the second largest production of lode gold is the Sitka district, which embraces the western portion of Chichagof and Baranof Islands. As has been noted, the discovery of gold-bearing veins in the vicinity of Sitka marked the first recorded recognition of the lode-gold mineralization in the Territory. Unfortunately these early finds did not turn out to be commercially attractive and even up to the present have not furnished any significant amounts of gold. North of Sitka, however, gold-bearing veins of great value have been found, notably in the vicinity of Klag Bay and of Kimshan Cove, with smaller production from mines farther north, adjacent to Lisianski Inlet. Under ordinary conditions it would not have been permissible to subdivide the production of the Sitka district among the smaller areas as the records in each relate mainly to those for a single mine. However, specific permission for releasing their statistical records having been granted by the Chichagoff Mining Co., the principal company in the Klag Bay area, and the Hirst-Chichagof Mining Co., the principal one near Kimshan Cove, it has been desirable to make these two subdivisions and to place the production from all the other parts of the district in a separate column headed "Other areas." The two larger mines were examined by Overbeck ${ }^{73}$ in 1917 and by Reed in 1938. The accompanying notes have been summarized from a preliminary report by Reed. ${ }^{74} \mathrm{~A}$ more comprehensive report will appear later. ${ }^{74 a}$ In general the mineralization at both the principal localities, Klag Bay and Kimshan Cove, occurs along the western flanks of the Chichagof-Glacier Bay anticline in Mesozoic graywackes and shales that have been cut by faults or fault zones. The trend and dip of the faults cut across the bedding of the sedimentary rocks at relatively small angles; the faults trend about N. $28^{\circ} \mathrm{W}$. and dip $72^{\circ} \mathrm{SW}$., whereas the bedding trends about N. $62^{\circ} \mathrm{W}$. and dips $67^{\circ} \mathrm{SW}$. The ore bodies lie in the shear zone and are tabular in shape with their longer axes in general more or less vertical, with a pitch to the south-

\footnotetext{
${ }^{73}$ Overback, R. M., Geology and mineral resources of the west coast of Chichagof Island : U. S. Geol. Survey Bull. 692, pp. 114-118, 1919.

${ }^{74}$ Reed, J. C., Preliminary report on the ore deposits of the Chichagof mining district : Am. Inst. Min. Met. Eng., Tech. Pub. 1051, March 1939.

74a Reed, J. C., and Coats, R. R., Geology and ore deposits of the Chichagof mining district, Alaska : U. S. Geol. Survey Bull. 929 (in press).
} 
east. Although formed subsequent to the major period of faulting in the area, the ore deposits have undergone some postmineral faulting that probably caused only slight displacement. The ore has a considerable vertical range, some of the bodies that have been mined occurring at elevations of about 2,000 feet, whereas others have been followed to depths of nearly 2,700 feet below sea level. Although production from the Klag Bay and Kimshan Cove areas is treated here as coming from entirely separate areas, it should be understood that the principal mine in each is separated from the other by only a short distance, as they lie on opposite sides of the same mountain. In fact, in places the underground workings of the two mines lie within less than half a mile of each other.

\section{COPPER RIVER REGION}

Lode-gold mining has never been carried on actively in the Copper River region. As has been stated in the section of this report dealing with the early history of lode mining in the Territory, goldbearing veins have been found at a number of places throughout the Copper River region, but as yet none of them have been developed to the stage of furnishing a continuing or large output. The small production recorded in table 5 as having come from the region from 1918 to 1924 was derived mainly from deposits in the KotsinaKuskulana district, which were developed for both their gold and copper content. All the mineral deposits of this area have been described in a report by Moffit and Mertie, ${ }^{75}$ who also noted separately those that are mainly valuable for the gold they carry. The conclusion they reached indicated that the veins that were mainly valuable for their gold content gave better promise of early production than those in which copper was the principal metal. This early promise was not fulfilled, for work on all the deposits was discontinued after a few years.

The lode-gold production recorded for the later years in the Copper River region has all come from deposits near the head of Golconda Creek, a tributary of Bremner River. The developments at this place were described by Moffit ${ }^{76}$ as consisting of a number of mineralized veins on which prospecting work had been done. A mill was built at one of the more promising properties in 1935 , but after it had been running a short time various difficulties arose which were not satisfactorily solved, and ownership of the property changed

${ }^{75}$ Moffit, F. H., and Mertie, J. B., Jr., The Kotsina-Kuskulana district, Alaska : U. S. Geol. Survey Bull. 745, 149 pp. (especially pp. 140-146), 1923.

${ }^{70}$ Moffit, F. H:, Recent mineral development's in the Copper River region : U. S. Geol. Survey Bull. 880-B, pp. 99-102, 1937. 
hands. The new owners since coming into possession have been engaged mainly in development work that up to the end of 1937 had not led to productive operation.

\section{PRINCE WILLIAM SOUND REGION}

The earliest lode-mining activities in the Prince William Sound region were concerned mainly with copper deposits, and, although these yielded some gold as a byproduct, it was not until 1909, following the opening up of the Cliff mine and some of the other mines near Valdez, that the amount of gold produced annually from this region was of much general significance. The early history of mining in the region up to 1914 was summarized by Johnson ${ }^{77}$ in the "Mineral resources of Alaska" for 1914, and supplementary information is given in many of the succeeding volumes of that series. The sudden decrease in the output of lode gold from the region after 1918 was in large measure due to an accident at the Cliff mine, through which the workings became flooded with water from the nearby sea and were put out of commission for many years. Meanwhile a number of other mines had begun to be opened up, especially in the western part of the region in the Port Wells and adjacent areas. A description of the lode mining activities in the Port Wells area up to the close of 1913 was prepared by Johnson, ${ }^{78}$ in which he recorded more than 50 mines and prospects at which mineral developments had been in progress. The mineralization throughout the area is regarded as having taken place in the late Mesozoic, probably following closely on the intrusion of granitic masses. Most of the ore that has been mined contains free-milling gold with which is associated sulphides of lead, zinc, arsenic, antimony, and copper. In 1933 attempts were made to unwater the old Cliff mine, but after the work had been in progress for several months it was abandoned and the property later disposed of to a new group of operators, who have succeeded in sinking new shafts and have finally unwatered the mine and begun productive mining. In the meanwhile, stimulated by the higher price of gold, the other mines made noteworthy production, so that the region took on again some of the importance as a lode-gold producer that it formerly had.

\footnotetext{
77 Johnson, B. L., The gold and copper deposits of the Port Valdez district: U. S. Geol. Survey Bull. 622, pp. 140-188, 1915.

78 Jahnson, B. L., The Port Wells gold-lode district: U. S. Geol. Survey Bull. 592, pp. 195-236, 1914.
} 


\section{COOK INLET-SUSITNA REGION}

\section{WILLOW CREEK DISTRICT}

Lode-gold prospects are widely distributed in the Cook InletSusitna region, but the only producing ones may be grouped into two rather distinct districts; namely, the Willow Creek district and Kenai Peninsula and adjacent areas. The Willow Creek district embraces an area that takes its name from one of the principal streams traversing it, which is a tributary of Susitna River. It lies some 50 miles north of Anchorage, which is situated near the head of Cook Inlet. Its geology and mineral deposits have been described by Capps ${ }^{79}$ and Ray, ${ }^{80}$ who give additional references to many other reports on the district. Starting with a very small production in 1911, the lodes of the district have been exploited on an ever-increasing scale, until in 1925 the output for that year was worth more than $\$ 450,000$. Then various misfortunes befell them among them a serious fire at one of the larger mines, which caused the production to drop off and almost cease during 1929 and 1930. Reorganization of the largest property and the installation of a complete change in the milling practice soon resulted in the district resuming its former rate of production and in a few years, owing also to the increased unit price of gold, outstripping all former marks, in 1934 almost reaching a production of $\$ 1,400,000$. Some changes in ownership of the various properties then ensued, which for a time led to a decline in the rate of production, but the curve has again turned definitely upward. Though as yet lode-gold production from the Willow Creek district is much below the high mark set in 1934, in 1937 it was above the record of any other year.

\section{KENAI DISTRICT}

The lode-gold mines in the Kenai district of the Cook Inlet-Susitna region can be grouped naturally into three more or less distinct areas, which center around Nuka Bay, in the southern part of the Kenai Peninsula; around the country adjacent to Moose Pass, including that part of the peninsula extending southward from the old settlements of Hope and Sunrise; and around Girdwood, which lies north of Turnagain Arm and is not, strictly speaking, part of Kenai Peninsula. It has not been considered advisable to publish the distribution of lode-gold production among these different areas, as to do so would reveal confidential information, and the available

\footnotetext{
${ }^{70}$ Capps, S. R., The Willow Creek district, Alaska. U. S. Geol. Survey Bull. 607, 86 pp., 1915.

${ }^{80}$ Ray, J. C., The Willow Creek gold-lode district, Alaska : U. S. Geol. Survey Bull. 849-C, pp. 165-230, 1933.
} 
records are not detailed enough to afford an accurate basis for such separation. It may, be stated, however, that the largest amount of lode gold has come from mines in the Moose Pass area and that successively smaller quantities have come from the Nuka Bay area and the Girdwood area. The most comprehensive or latest reports issued by the Geological Survey un these various areas are those on the Moose Pass area, by Tuck ${ }^{81}$ and Johnson; ${ }^{82}$ on the Nuka Bay area, by Capps; ${ }^{83}$ and on the Girdwood area, by Park. ${ }^{84}$

In the extreme northern part of the Cook Inlet-Susitna region is the Valdez Creek district, which so far has produced only an insignificant amount of lode gold during one year, 1935. In table 5 it has been included in the column for the Kenai district. This procedure did not alter the total for the Kenai district by as much as 1 percent, so that its effect was practically negligible. Description of the Valdez Creek district may be found in the reports by Ross ${ }^{85}$ and Tuck. ${ }^{86}$

In the extreme northern part of the Cook Inlet-Susitna region some lode-gold developments have been in progress for a number of years in the vicinity of the West Fork of Chulitna River, which, in turn, is a tributary of Susitna River. As yet no noteworthy production of lode gold has come from this area, but new developments were in progress late in 1936 that bid fair to establish a really significant lode-mining industry in the near future. The deposits were described by Ross, ${ }^{87}$ who examined them in 1931 and stated that the various types showed extensive mineralization, though it was impracticable to estimate the quantity of ore that might be profitably developed. Capps ${ }^{88}$ described the new work that was in progress in 1936, and that information was supplemented later by Smith. ${ }^{80}$ These recent reports show that the developments were planned to permit of mining being done on a rather large scale and that they had progressed far enough to indicate that productive mining would be started not later

\footnotetext{
si Tuck, Ralph, The Moose Pass-Hope district, Kenai Peninsula, Alaska: U. S. Geol. Survey Bull. 849-I, pp. 469-527, 1933.

${ }^{82}$ Martin, G. C., Johnson, B. L., and Grant, U. S., Geology and mineral resources of Kenai Peninsula, Alaska: U. S. Geol. Survey Bull. 587, 243 pp. (especially pp. 128-176), 1915.

${ }^{83}$ Capps, S. R., in Smith, P. S., Mineral industry of Alaska in $1936:$ U. S. Geol. Survey. Bull. 897-A, pp. 25-32, 1938.

${ }^{84}$ Park, C. F., Jr., The Girdwood district, Alaska: U. S. Geol. Survey Bull. 849-6, pp. $381-424,1933$.

${ }^{85}$ Ross, C. P., The Valdez Creek mining district, Alaska: U. S. Geol. Survey Bull. 849-1-I, pp. 425-468, 1933 .

${ }^{80}$ Tuck, Ralph, The Valdez Creek mining district in 1936 : U. S. Geol. Survey Bull. S97-B, pp. 109-131, 1938.

${ }^{87}$ Ross, C. P., Mineral deposits near the West Fork of the Chulitna River, Alaska: U. S. Geol. Survey Bull. 849-E, pp. 289-333, 1933.

${ }^{83}$ Capps, S. R., in Smith, P. S., Mineral industry of Alaska in $1936:$ U. S. Geol. Survey Bull. 897-A, p. 34, 1938 .

${ }^{80}$ Smith, P. S., The mineral industry of Alaska in 1937 : U. S. Geol. Survey Bull. 910-A, 113 pp., 1939.
} 
than 1940. In addition to gold, the ore contains copper and silver. According to the present operators the ore is expected to yield a concentrate containing about 6 ounces of gold, 15 percent copper, and 40 ounces of silver to the ton of concentrate. This concentrate would be shipped to the States for treatment. The concentrate that is shipped is expected to contain about 65 percent of the gold in the original ore, the remaining 35 percent being recovered in a mill near the mine by cyanidation of the iron sulphides, which could not be shipped profitably.

\section{SOUTHWESTERN ALASKA}

\section{UNGA DISTRICT}

The principal district in southwestern Alaska in which lode-gold mining has been successful is in the vicinity of Unga Island, one of the group forming the Shumagin Islands, off the extreme southerly part of the Alaska Peninsula. The early history of lode mining in this area has already been traced in some detail in earlier pages. (See pp. 186-187.) Large-scale mining there had ceased before 1906, and though later there was revival of mining and small amounts of gold continued to be recovered during the period from 1908 to 1913, its value was small, and with the oncoming of the World War even work on that scale was suspended. Though the mine is still kept in a more or less stand-by condition, it has lain dormant ever since. One difficulty that was experienced was apparently due to the falling off in the content of free gold and the greater amount of the mixed sulphides that were encountered in the lower levels of the mine. These deeper ores contained considerable lead, copper, and zinc, in addition to gold and silver. As methods for separating these various components had not been satisfactorily worked out in the early days of the mine, much ore that probably could now be successfully treated by flotation was then passed by as not worth mining. 'Some of these bodies of complex ore are said to have been from 10 to 24 feet in width and to have averaged 12 to 14 feet in width. ${ }^{90}$

\section{OTHER DISTRICTS}

The small amounts of lode gold attributed to other lode properties in southwestern Alaskn and shown in table 5 in the appropriate column, under the heading "Other districts," came from small mines on Kodiak Island and from lodes of mixed sulphides near Iliamna Bay, near the base of the Alaska Peninsula. As is evident, only negligible amounts of gold derived from these sources have been re-

\footnotetext{
${ }^{80}$ Brown, F. R., Notes on Apollo Consolidated Gold Mining Co. Typed statement made about 1928. On file in the Alaskan Branch of the Geological Survey.
} 
covered. The gold lodes as well as other features of Kodiak Island have been described by Capps ${ }^{91}$ and those in the vicinity of Iliamna Bay by Martin and Katz. ${ }^{22}$

\section{YUKON REGION}

Occupying most of central Alaska is the Yukon region, which at various places in its wide extent contains gold-bearing veins, some of which have been developed to support profitable mining industries. For the purpose of the present report the lode-gold production of only two of the principal districts, Fairbanks and Nabesna, will be set down separately by years, and that from all the others will be combined and set down in the column in table 5 under "Other districts" of the Yukon region.

\section{FAIRBANKS DISTRICT}

The development of the lode-gold deposits of the Fairbanks dis-. trict began soon after the camp's discovery in 1903, but it was 1910 before any significant amount of lode-gold was forthcoming. Then ensued a period of intense activity in the search for and development of the lode deposits, and production mounted to more than a third of a million dollars in 1913. The difficulty and cost of mining small veins, such as many of those of the Fairbanks district turned out to be, coupled with the general decline in mining activity throughout the Territory as a result of the World War, caused a great decrease in lode-gold production in 1916 and a lower rate of output than had theretofore prevailed at any time since the early days of the camp. This relatively low rate of production continued with but slight improvement until 1930, when the annual production passed the $\$ 130,000$ mark and progressively increased with but few downward dips until in 1937 it was $\$ 423,000$, a figure that had not been exceeded or even equaled in any of the other years that lodo mining had been in progress in the district. Not only have the later ye:urs been marked by greatly increased gold production but, what is perhaps even more significant, they have been years in which increased activity has been shown in lode-gold development not only by the small operator but by well-financed companies capable of undertaking large-scale developments should their preliminary investigations justify such action. It seems likely, therefore, that within a few years, if present trends continue, the annual output from the lode-gold mines of the district may become several times

\footnotetext{
or Capps, S. R., Kodiak and adjacent islands: U. S. Geol. Survey Bull, 880-C, pp. 111$184,1938$.

03 Martin, G. C., and Katz, I. T., A geologic reconnaissance of the Iliamna region, Alaska : U. S. Geol. Survey Bull. 485,138 pp. (especially pp. 116-126), 1912.
} 
greater than at present. Such growth will necessarily mean the handling of large amounts of relatively low-grade ore rather than attempting to mine only small veins of high tenor, as has been done in the past. Much of the early history of lode-gold developments in the Fairbanks district was given in reports by Prindle ${ }^{93}$ and Smith; ${ }^{94}$ later developments were given in a report by $\mathrm{Hill},{ }^{95}$ as well as in the subsequent annual reports on the "Mineral industry of Alaska" published by the Geological Survey.

\section{NABESNA DISTRICT}

In the Nabesna district there is only one producing mine at the present time. This is the property of the Nabesna Mining Corporation, located at White Mountain, near Jacksina Creek. The com. pany issues quarterly and annual reports descrioing its operations during the specified period, so that those facts, as well as the current production of the mine, are matters of public record. The figures set down in the column for the Nabesna district in table 5 do not tally exactly with those published by the company for the following reasons: The company does not report separately the value of gold and the other metals that are recovered from its ore, whereas in the accompanying table only the value of the gold is shown. The company's computations as to the unit price of the various metals recovered in many instances differ greatly from the unit prices adopted by the Geological Survey. Thus the unit price used by the company for its production of gold in 1933, which it unquestionably received for its output, was $\$ 27.43$ an ounce, whereas the unit price used by the Geological Survey was $\$ 20.67+$; in several of the earlier years the company's valuation of its gold was based on a price of $\$ 20$ an ounce rather than $\$ 20.67+$. Furthermore, certain bullion included in stacked middlings held at the mine are excluded by the company, though, included by the Geological Survey. In spite of these diversities of practice in computing the gold production of the mine, the end results are in surprisingly close agreement, because, according to the latest available report of the company, ${ }^{96}$ the gross value of metals recovered is given as $\$ 1,204,483$, whereas the figure computed according to the Survey practice and set down in table 5 for the total value of the gold produced is $\$ 1,204,216$. Brief descriptions of the Nabesna mine

${ }^{83}$ Prindle, L. M., Auriferous quartz veins in the Fairbanks district: U. S. Geol. Survey Bull. 442, pp. 210-229, 1920.

1913.

smith, P. S., Lode mining near Fairbanks: U. S. Geol. Survey Bull. 525, pp. 153-2.16,

${ }_{95}$ Hill, J. M., Lode deposits of the Fairbanks district, Alaska: U. S. Geol. Survey Bull. 849-B, pp. 229-163, 1933.

Dabesna Mining Corporation, General Manager's 8th Ann. Rept., for the year 19:37, 8 pp., 1938 . 
and of the country adjacent to it are contained in various recent reports by Moffit. ${ }^{97}$

\section{OTHER DISTRICTS}

The districts grouped together in table 5 under "Other districts" in the Yukon region include the following: Bonnifield, Iditarod, Innoko, Kantishna, and Chandalar. They are named in the relative order of their past lode-gold production, the Bonnifield district, with the largest recorded production being first, and the Chandalar, with the lowest production, being last. The early developments in each of these areas have already been mentioned (see pp. 171-175), but a few supplementary notes on later developments may be appropriate here.

Productive lode-gold mining in the Bonnifield district was largely limited to the period 1932 to 1935, inclusive, though earlier prospecting had long before that disclosed the presence of gold-bearing veins. The principal producing property was that of the Eva Mining Co., on Eva Creek, some 14 miles east of Ferry, a station on the Alaska Railroad. The ore carried free gold in a mixture of sulphides one of which contained considerable bismuth. This property was described by Moffit. ${ }^{98}$ The heavy and shattered condition of the rocks encountered underground in this mine made extraction of the ore extremely difficult and costly. Because of these conditions, rather than because of absence of vein material, the undertaking was discontinued in 1935. Somewhat to the north and east of the Eva mine, on California Creek, development of gold-bearing lead-silver deposits was in progress in 1934 and 1935, during the course of which considerable quantities of ore were obtained. The high cost of mining and transportation of the ore to smelters in the States, coupled with the small size and discontinuity of the leads, resulted in early cessation of work at this property.99 None of the prospects in the Wood River area, in the more northern part of the Bonnifield district, which were described by Capps, ${ }^{1}$ have yet afforded significant production, though some of the tests reported by him indicated that some of the material carried enough gold to make the ore of commercial grade, if the samples on which they were made were representative of any considerable volume of material.

\footnotetext{
${ }^{7}$ Moffit, F. F., The Suslota Pass district, upper Copper River region, Alaska: U. S. Geol. Survey Bull. 844-C, pp. 159-162, 1933; Recent mineral developments in the Copper liver region : U. S. Geol. Survey Bull. 880-B, pp. 103-104, 1937.

${ }^{68}$ Moffit, F. H., Mining development in the Tatlanika and Totatlanika Basins : U. S. Geol. Survey Bull. 836, pp. 340-345, 1933.

${ }^{\circ 0}$ Smith, P. S., Mineral industry of Alaska in 1935 : U: S. Geol. Survey Bull. 880-A, p. $28,1.937$. 1912 .

Capps, S. R., The Bonnifield region, Alaska: U. S. Geol. Survey Bull. 501, pp. 52-52,
} 
The production of lode gold in the Iditarod district took place mainly during 1935, when the Golden Horn mine, near the head of Flat Creek, was in operation. Mineralization on this property had long been recognized, and some attempts had been made earlier to open up the veins on a small scale but without success. In 1934 an attempt was made to develop the mine on a large scale and with modern equipment. During this work considerable ore was mined and gold recovered from it in a local mill and in the concentrates that were shipped to the States for treatment. The deposits that were disclosed by this work proved to be too small to be mined in the way planned, so the project was abandoned before the end of 1935. This action by no means proved that that property may not be worked profitably on a small scale, which would not be attractive to a large company that must handle large quantities of ore to defray its operating expenses. ${ }^{2}$

Little lode-gold mining has ever been done in the Innoko district, and the records of production received by the Geological Survey indicate that the amount of gold recovered from such work, except in 1912, was too small to be recorded. In that year the locie gold came from a single mine and was worth only a few thousand dollars. Eakin, ${ }^{3}$ who visited the Innoko district in 1912, gave a brief description of this property, which was situated at the head of Carter Creek, an eastern tributary of Ganes Creek. Mertie, ${ }^{4}$ who later revisited much of the area previously covered by Eakin, as well as additional adjacent areas, indicates that not only were no other lode mines in operation in the area but that little work had been done subsequent to Eakin's visit on the prospect mentioned by him.

Although mineralization has long been known to occur in the Kantishna district, in the northern foothills of the Alaska Range, there has as yet been an entirely inadequate amount of development done at any of the showings. It is true that up to a relatively recent time the district has been rather difficult of access, and the cost of prospecting has necessarily deterred operations. Most of the small amount of mining that had been done was of deposits which carried mainly lead, silver, or some metal other than gold, with only subordinate amounts of gold. During the years 1920 to 1924, inclusive, there were a number of shipments of ore in which gold was but a minor constituent. Several veins, however, have been found in the district that carry gold as the principal mineral of value. Although some explorations of these lodes have been made by

2 Smith, P. S., op. cit., p. 27. .

8 Eakin, H. M., The Iditarod-Ruby region, Alaska: U. S. Geol. Surveg Bull, 578, p. 40, 1914.

4 Mertie, J. B., Jr., and Harrington, G. L., The Ruby-Kuskokwim region, Alaska: U. S. Geol. Survey Bull. 754, p. 115., 1924. 
underground workings and many rich samples taken as a result of that work, no serious attempt to mill the ore locally had been made up to the close of 1937. Moffit, ${ }^{5}$ who visited the district in 1930 , prepared a comprehensive statement regarding the mining activities not only at the lodes in which gold is the principal mineral of value but also at those in which other metals occur. In that report (p. 328) he refers to the fact that about 100 tons of ore was obtained from the Red Top claim, of which 6 tons averaged about 0.88 ounce of gold to the ton and the rest averaged about 2.53 ounces, making the value of the gold in the 100 tons of ore about $\$ 5,000$. This accounts for almost the entire production of gold from the district to date. A somewhat fuller description of the various mining properties in this district is afforded by the report of Wells, ${ }^{6}$ who made examination in it in 1931. Developments undertaken late in 1938 to open up certain of the lodes near the head of Friday Creek seem likely to increase greatly the production of lode gold from the district.

Although from time to time much is heard about the potential lode-gold resources of the Chandalar district, in the northern part of the Yukon region, little actual development work as yet has been done to demonstrate the validity of those statements. It is true that the district is one of the least accessible of any of those in the Yukon region and the season is especially short, so that the difficulties and costs. of operation are especially great. It cannot be doubted that gold-bearing veins occur in the district, but none of those so far found have proved capable of successful development under present conditions. The total lode-gold production from the district in the past, according to the Geological Survey records, has been worth only a very few thousand dollars. The lode deposits of this district have been described by Maddren ${ }^{7}$ and Mertie. ${ }^{8}$

In addition to the value of the lode gold directly attributed to these various districts in the Yukon region, the records show gold worth $\$ 13,000$ as having been derived from the region but whose source is not definitely known. Possibly part or all of it may have come from some of the districts or camps specifically mentioned and should have been included in the figures given, or it may have come from other: unidentified areas. The amount involved, however, is so small that it might well be disregarded, except as its omission

\footnotetext{
${ }^{5}$ Mofft, F. F., The Kantishna district: U. S. Geol. Survey Bull. 836, pp. 325-334, 1.933.

'Wells, F. G., Lode deposits of Dureka and vicinity, Kantishna district, Alaska: U. S. Geol. Survey Bull. 849-F, pp. 335-379, 1933.

"Maddren, A. J., The Koyukuk-Chandalar region, Alaska: U. S. Geol. Survey Bull. 532, pp. 111-115, 1913.

8 Mertie, J. B., Jr., Geology and gold placers of the Chandalar district, Alaska: U. S. Geol. Survey Bull. 773, pp. 261-263, 1.925.
} 
would vitiate the mathematical accuracy of the tabulations. It consequently has been carried in the column headed "Other districts" in the Yukon region.

\section{KUSKOKWIMI REGION}

In spite of its enormous extent there has been only little production of lode gold in the past from any part of the Kuskokwim region. This condition is believed to be due mainly to the lack of exploration rather than to the absence of mineral deposits of value. The remoteness of most of the region from ordinary routes of transportation and travel has discouraged prospectors from plying their search far afield in it, as they realize the difficulties and high expense they would be put to in trying to develop or dispose of any finds they were fortunate enough to make. Even with the small amount of prospecting that has been done, however, many indications of lode mineralization have been discovered, and doubtless many more would have been found had the region been combed more thoroughly. From such fragmentary information as is now available concerning the geology of the region, it is evident that processes similar to those that have formed minable deposits of minerals in other parts of the Territory have been active at many places in the Kuskokwim region also. Thus the great arc of the Alaska Range, which was the scene of many deep-seated processes attendant on the formation of mineral deposits in the eastern part of the range, forms the highland in which rise many of the tributary streams in the eastern part of the Kuskokwim region. The placer deposits near McGrath, Takotna, Georgetown, Nyak, Goodnews Bay, and the Russian Mountains doubtless derived their minerals of value from bedrock sources within the Kuskokwim Basin. The quicksilver deposits near Sleitmut and Barometer Mountain bear further evidence of the mineralizing action that has taken place in parts of the region. Capps, ${ }^{9}$ in describing parts of the Alaska Range that fall within the basins of streams tributary to Kuskokwim River, refers to the fact that although no rich lode deposits have been found in that area the geologic relations suggest the likelihood that lodes may occur, and he mentions a number of places in that part of the region where mineralization was actually observed.

Such lode-gold mining as has been done in the Kuskokwim has centered largely in the hills that lie some 30 to 40 miles northeast of McGrath and north of the Kuskokwim River, in the McKinley district. A few scattered lode prospects in the western part of the Kuskokwim Valley, especially in the Russian Mountains north of Akiak, have from time to time afforded small lots of lode gold.

${ }^{9}$ Capps, S. R., The southern Alaska Range: U. S. Geol. Survey Bull. 862, p. 89, 1935. 


\section{MCKINLEY DISTRICT}

The production of lode gold from the mines in the McKinley district is tabulated together in the column for that district. As is evident from table 5, the first significant output of lode gold from the McKinley district was in 1920. Then followed a period of great activity during which lode gold worth several hundred thousand dollars was taken from the three principal mines in the area, as well as from a number of smaller prospects. By 1925, however, the boom era had passed, though certain of the properties continued to operate on ar reduced scale, and in the 11-year period from 1927 to 1937 , inclusive, have yielded gold to the value of more than $\$ 430$,000 . Owing to the fact that at times during the later years only one mine was active in the district, it has been necessary, in order to avoid revealing current confidential information, to combine the production of the 5-year period, 1933 to 1937 , inclusive, and to state it as a single figure.

The latest summary report on the geology and ore deposits of this part of the McKinley district is that by Mertie, ${ }^{10}$ who conducted examinations there in 1933. In his report, Mertie has supplemented his own observations by those made in earlier years by Martin ${ }^{11}$ and Brown. ${ }^{12}$ The principal gold lodes lie near the contact of monzonitic intrusives, of Tertiary age, with Paleozoic limestones. The ore bodies, as a rule, have developed in the limestones within a hundred feet or so of the contact. In addition to the gold, the ores carry considerable values in copper and silver. Present operations at the largest of the producing mines are much hampered by lack of an adequate supply of water for milling, which is now done only during a part of the open season.

\section{OTHER DISTRICTS}

Practically no detailed information is available regarding the geology and local features near the lode deposits from which came the small production attributed to the other districts in the Kuskokwim Valley. As already noted most of this gold came from deposits in the Russian Mountains. Maddren ${ }^{13}$ refers to a deposit of goldbearing antimony ore near the contact of an igneous intrusive with the sedimentary rocks at the head of Mission Creek in the southern

\footnotetext{
${ }^{10}$ Mertie, J. B., Jr., Mineral deposits of the Ruby-Kuskokwim region: U. S. Geol. Survey Bull. 864-C, pp. 229-242, 1936.

${ }^{11}$ Martin, G. C., Gold lodes in the upper Kuskokwim region: U. S. Geol. Survey Bull. 722, pp. $149-161,1922$.

${ }^{19}$ Brown, J. S., The Nixon Fork country : U. S. Geol. Survey Bull, 783, pp. 97-144, 1926.

${ }^{13}$ Maddren, A. J., Copper in the Russian Mountains: U. S. Geol. Survey Bull. 622, pp. 358-359, 1915.
} 
part of the Russian Mountains. He also describes a deposit of metallic sulphides within the area occupied by massive intrusive rocks at the head of Cobalt Creek, which flows northward into Owhat River. The deposit at the head of Cobalt Creek seems to have been the one at which most work was done, as Maddren reports that it had been traced for a considerable distance on the surface and opened up by a shaft about 40 feet deep. So far as known, no milling equipment has been installed on the property.

\section{SEWARD PENINSULA}

The production of noteworthy amounts of lode gold from mines in Seward Peninsula was rather closely restricted to the early years of mining there, because the principal producing mine, that of the Hurrah Quartz Mining Co., ceased operations in 1907 and was not again reopened for other than desultory work. In spite of the rather insignificant production of lode gold in later years there has always been a considerable amount of prospecting for lodes in progress, and many indications of lode mineralization have been reported in practically all parts of the peninsula. Cathcart ${ }^{14}$ in 1920 summarized what was then known about the metalliferous resources of the southern part of the peninsula and referred to an extremely impressive number of places where mineralization had been recognized. His description of these occurrences included not only those deposits that are principally of value for their gold content but also those in which other metals are predominant. At several of these places some work is currently in progress on a small scale, and at three, at least, in addition to the one at the Big Hurrah mine, mills have been built to treat the ore. Rumors that plans for the reopening of some of these properties are in contemplation are in common circulation, and it seems not at all unlikely that attempts will be made to carry through some of these plans in the near future. For instance, the "Mineral industry of Alaska in 1937" is records the fact that in the Nome, Solomon, and Bluff districts of the peninsula prospecting and development work were then in progress, -which appeared likely to bring certain of the properties into production in 1938. True, these promises for the properties in the Solomon and Bluff districts were not fulfilled as soon as then indicated, but the developments at at least one property, near the head of Snake River, in the Nome district, have placed it among the lode mines that yielded a return in gold, both in 1937 and 1938. It is still with considerable con-

\footnotetext{
${ }^{14}$ Cathcart, $\mathrm{S}, \mathrm{H}_{1,}$ Metalliferous lodes in southern Seward Peninsula, Alaska : U. S. Geol. Survey Bull. 722, pp. 163-261, 1922.

${ }^{15}$ Smith, P. S., Mineral industry of Alaska in 1937 ; U. S. Geol, Survey Bull, 910-A, 113 pp., 1939.
} 
fidence that the writer predicts that Seward Peninsula mines will again furnish considerable lode gold to swell the total output of the Territory.

\section{UNIDENTIFIED REGIONS}

The column at the extreme right in table 5 has been headed "Unidentified," and in it has been recorded the production of lode gold that was reported by smelters, assay offices, mints, and other purchasers as having come from Alaska ores but the exact source of which it has been impossible to determine. As will be seen, the total value of the gold thus designated is less than $\$ 13,000$, an insignificant amount in comparison with the total amount of lode gold that has come from the Territory. Doubtless this gold actually came from some of the areas specifically carried in other columns of the table and properly should have been included had adequate information as to its point of derivation been known. It should be noted that this column serves a purpose entirely different from that served by the columns headed "Other areas" or "Other districts" that appear under certain of the regions, such as southeastern Alaska, Yukon, and Kuskokwim, for the figures tabulated in those columns definitely came from those regions, whereas those noted in the columns as unidentified may have come from any part of the Territory. 



\section{INDEX}

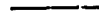

Page

Abstract-_rage $\begin{array}{r}\text { Page } \\ 159\end{array}$ Fairbanks, gold near

Admiralty Island area, production of

gold from-a $-1.80,184,192-193$

Fairbanks district, production of gold

Flat Creek, gold near.

Alnska Juneau mine, production of $183-184$ gold from_.. $18.8-184$.

Alaska Mexican Gold Mining Co., operations by

Alaska Treadwell Mining Co., operations by

Alaska United Gold Mining Co., operations by ........

181

181

181

169

Annette Island, gold on---_-----

Apollo Consolidated mine, production of gold from_.._ 186-187

Auke Lake, gold near

169

Bedrock Creek, gold on

Berg Creek, gold near.....--_-_--

Berners Bay area, production of rold from

$\overline{1} \mathbf{8 0}, \overline{1} \overline{8} \overline{1}-185,192$

Big Furrah Creek, gold near-..--- 169-170

Big Hurrah mine, operations at_-- 169-170

Boca de Quadra, gold near._._._. 169

Bonnifield district, gold in____-_- 174, 203

Boston \& Alaska Co., operations by -- 184

Bremner district, gold in_-_._._.-- 174

Cilifornia Creek, gold on__._._._. 203

Carter Creek, gold near-_._-_- 171-172, 204

Chandalar oistrict, gold in_-_-_-_ 172, 205

Chichagof Island, gold on_-_._-_- 170

Cleveland leninsula, gold on_.....- 169

Cliff mine, early history of _-_._- 170-171 operations at _... 197

Cobalt Creek, gold near-..._._-_.-- 208

Comet mine, production of gold from- 185

Cook Inlet, discovery of gold at_._. 170

Cook Inlet-Susitna region, production of gold firom-- $198-200$

Copper, occurrence of ---- 169, 170, 200, 207

Copper River region, production of

gold from-- $\overline{174}, \overline{178,196-197}$

Douglas, discovery of gold near.

Douglas Island area, production of gold from-_..- 180, 188-189

Eagle River area, production of gold from__._ $168,180,185,192$

Ebner mine, production of gold

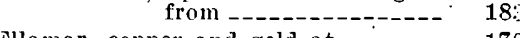

Ellamar, copper and gold at_-_-_- 170

Eva Creek, gold on__-___-_._-_ 174, 203

Eva Mining Co., operations by...- 203
Friday Creek, gold near._._. 205

Girdwood district, gold in_--- 171, 198-199

Glen Gulch, gold near._-_-_-_-_ 173

Golconda Creek, gold near-_.-_-_- 196-197

Gold, production from lodes, by regions _. regions
production from lodes, early future prospects for since 1905 to close of 1905 to close of $1987-159,-17 \overline{5}-178,179$ Sec also regions, districts, and areas.

Gold Creek area, production of gold from --- - - -

Golden Horn mine, production of
gold froin 183

Gravina Island, gold on

204

169

Hirst-Chichagof mine, production of gold from

Hyder district, production of gold fiom - 194

Iditarod district, gold in_______-_ 173, 204

Iliamna Bay, gold near-_-_-_.--- 200-201

Indian Creek, gold on____._. 168

Innoko district, gold in_-_.-- 171-172, 204

Jacksina Creek, gold near_____ 173-174, 202

Jualin mine, production of gold from_ 185

Juneau, discovery of gold near.--_ 168-169

Juneau area, production of gold

from -..... 180, 182-184

Juneau district, production of gold from - $180,181-185,188-193$

Kantishna district, gold in--- 173, 204-205

Kenai district, production of gold from

Kenai Peninsula, discovery of gold on

Ketchikan district, discovery of copper and gold in production of gold from $18 \overline{6}, \overline{1} 94-195$ Kimshan Cove, gold near-_-_- 173, 195-196 Klag Bay, gold near-_._._._. 170, 195-196 Knopf, Adolph, quoted_._._. 192 Kodiak Island, gold on_-_._-_-_- 200-201 Kotsinn-Kuskulana district. copper and gold in ......- 196

Kuskokwim region, production of gold from

Kuskokwim River. discovery of gold and silver on 
Kušsulana area, gold in

Latouche Island, copper and gold onLead, occarrence of -

Lisianski Inlet, gold near........

Lode gold. See Gold; names of regions, districts, and areas.

McKinley district, production of gold from

McKinley Lake area, gold in._-_.--- 172

Mexican mine, production of gold fiom_... 182, 189

Mission Creek, gold near-_._._-_- 207-203

Moose Pass area, gold in_._.- 171. 198-193

Nalesna district, discovery of gold in production of gold from---- 202-203

Nabesna Mining Corporation, operations by-_- 202-203

Nabesna River, gold near-_._._._-_ 173

Nome district, gold in__-_._____- 203

Nuka Bay area, gold in_-_._- 171, 198-199

Perseverance mine, production of gold from

l'ort Wells area, gold in

Prince of Wales Island, gold on__-_. 169

Prince William Sound region, copper

in

production of gold from.$--\begin{gathered}170-171, \\ 178,197\end{gathered}$

Ready Bullion mine, production of gold from

Records of production, character and presentation of _._._. 160-167

Red Top claim. production of gold from _........ 205

Rhoads-Hall prospect, early history of

Russian Mountains, gold in
Page Foot mine, production of gold
from Seward Peninsula, discovery of gold $169-170$ production of gold from- 178 $180, \overline{187}, \overline{2} 08-209$

Sherman Creek, gold near._-_-_-_ 169

Shuck River, gold on__-_____._- 193

Silver, occurrence of

silver Bow Basin, gold in_..._._._-_ 168

Sitka, gold near._._._._._. 168

Sitka district, production of gold

- from-_-_-_-_-_- 195-196

Snake River. gold near._-_-_-_-_- 208

Snettisham, gold near-_._______ 169, 193

Southeastern Alaska, production of 178-179

$180-186,187,188-196$

Southwestern Alaska, production of gold from

Sumdun, gold near. 193

Taku Inlet, gold near._._._..... 193

Treadwell mine, production of gold from - - - 181-182, 188-189

Unga district, production of gold from_-_._ 169, 186-187. 200

Valdez, gold near-_._._..._-_._- 170-171

Valdez Creek district, gold in_ 174-175, 199

IVest Fork of Chulitna River, gold near.

Willow Creek district, production of gold from

Windham Bay area, gold in

Woewodski Island, prospecting on 194-195

Wood River area, gold in_______.- 203

Yukon region, production of gold from-_. $175,178,201-206$

Zinc, occurrence of 